\title{
Chapter 7 \\ Evaluations from Different Parties on Influenza A (H1N1) Prevention and Control
}

Assessments of policy formulation and implementation by domestic and international stakeholders, especially domestic stakeholders, comprise a crucial component of policy evaluation. The end goals of the state's prevention and control efforts were: to ensure the protection of public health and safety, protect social order, and maintain the status quo in work and life. Thus, assessments on the state's responses by patients, close contacts, medical personnel, the public, and international community could reflect in many ways the degree of completion for expected objectives and the social effects of adopted prevention and control efforts.

In order to objectively evaluate the assessments on the state's response to Influenza A (H1N1) by patients, close contacts, medical personnel, and the public, this research group conducted the following data collection: questionnaires for 3262 randomly sampled residents across the country, phone interviews with 893 Influenza A (H1N1) patients and 646 close contacts from Beijing, Fujian, and Henan areas, and field interviews with 519 personnel from 31 disease control agencies and 243 medical personnel from 29 key hospitals in Beijing, Fujian, Henan, Guangdong, and Sichuan. In order to gauge the international community's assessments on China's response to the pandemic, this research group also conducted interviews and field surveys with the WHO, along with a literature review of international media.

\subsection{The Public's Assessment}

The public's satisfaction with the central government's response to Influenza A (H1N1) reflects their assessment of the state's overall performance in the prevention and control of the virus. The changes in the level of public trust in the state's emergency response capabilities also reflects the credibility of the government in handling emergencies, and it also gives credence to the efficient communication between government and society. The effect of individual differences in 
satisfaction to a certain extent reflects the impact of specific prevention and control measures on different groups of people.

Based on the above presumptions, in order to objectively gauge the public's assessment on the state's response to Influenza A (H1N1), the assessment group worked with the Horizon Surveying Company to conduct door-to-door surveys with 3262 randomly sampled residents across the country. These surveys analyzed the following: the level of satisfaction regarding the central government's overall performance in its prevention and control efforts; the perceived effectiveness of the Prevention and Control Mechanism established by the central government; level of satisfaction in the local government's (including sub-district office; and government from the town and township level to the provincial level) overall performance in prevention and control; the level of trust or changes of trust in the central government's and local government's (including sub-district office, and government from the town and township level to the provincial level) emergency response capabilities (after experiencing the Influenza A (H1N1) epidemic); and information credibility provided by the central and local governments.

\subsubsection{The Public's Satisfaction Assessment of the State's Influenza A (H1N1) Prevention and Control Efforts}

As the outbreak of Influenza A (H1N1) constituted a national public health emergency, the central government took the lead by forming a Prevention and Control Mechanism and also by formulating an overall response strategy. Under the guidance of this strategy, local governments then adopted relevant measures to mitigate the disaster. Assessing the level of public satisfaction of the government's efforts means we must evaluate the overall performance of the government in mitigating this epidemic. The strategies made by the central government needed to be carried out by the local governments, and the extent to which measures were implemented directly affected the efficiency of prevention and control efforts. Therefore, the public's level of satisfaction of the local government's (including governments at the provincial, municipal, county, town and township level, and sub-district offices) overall performance in prevention and control is actually based upon their direct perception of how the measures were implemented in their local area.

\subsubsection{Nearly 92\% of the Public Was Satisfied with the Central Government's Performance}

In mitigating the Influenza A (H1N1) pandemic, a large portion of the sampled public, nearly $92 \%$, expressed their satisfaction in the central government's overall performance. Among these, $44.9 \%$ of respondents stated they were very satisfied 


\section{Level of satisfication with the central government}

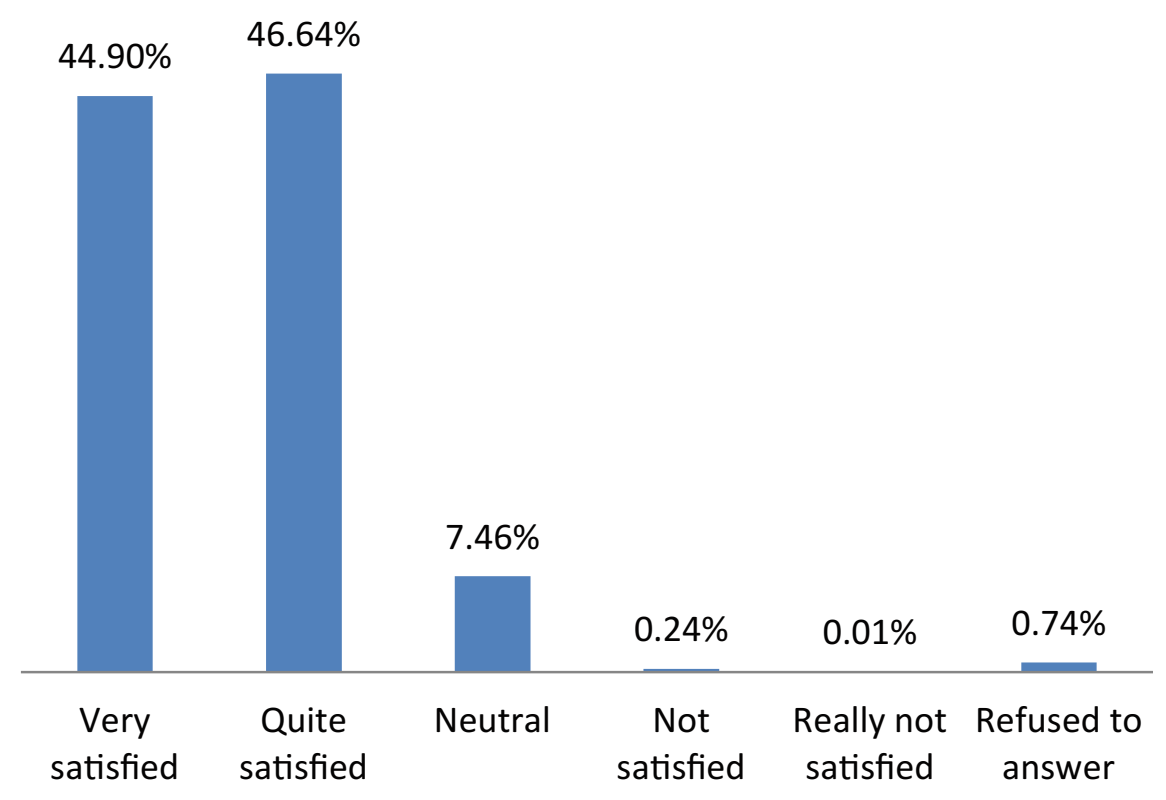

Fig. 7.1 Public's satisfaction in the central government's response to Influenza A (H1N1)

with the government's response efforts, $46.64 \%$ expressed they were quite satisfied, and $0.25 \%$ stated they were dissatisfied with the efforts (Fig. 7.1).

As can be seen in the data, individual characteristics within the public didn't significantly impact their assessment of the central government's response efforts, and it is evident that satisfaction with the state's efforts was prevalent among the masses. In regards to overall satisfaction, we investigated the impact demographics and other characteristics may have on the public's assessment. Using one-way analysis of variance, we found that factors such as gender, age, educational background, income, residence, experience with infectious disease, and having children had no significant impact on the level of satisfaction in regards to the central government's responses. After dividing the respondents according to age, income, and gender respectively, we found that more than $90 \%$ of the respondents felt satisfied with the government, which was accordance with the overall situation.

There were some significant differences in the level of satisfaction among different occupations and industries. The results of the study showed that middle to upper level management in enterprises expressed higher satisfaction than their peers in government bodies and public institutions. Over $90 \%$ of enterprise management expressed their satisfaction with the central government, while over $80 \%$ in government bodies and public institutions answered as being satisfied. After separating the groups by industry, we found that the education sector and the hotel and restaurant sector had lower levels of satisfaction than the average value (Fig. 7.2). 


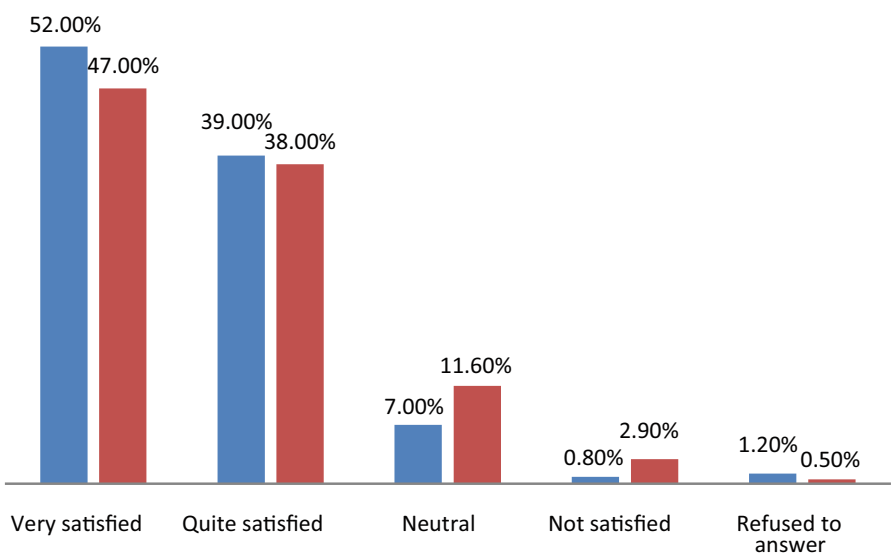

Fig. 7.2 Hotel and restaurant sector's and education sector's satisfaction with the central government's response efforts (Unit: \%)

\subsubsection{Ninety-Three Percent of the Public Aware of the Prevention and Control Mechanism Found It to Be Effective}

In our assessment, we paid special attention to the public's level of satisfaction with the Prevention and Control Mechanism, as it played a pivotal role in the central government's response efforts. Among the respondents, $36.13 \%$ knew that the State Council had established such a mechanism, out of those who were aware of it, $57.09 \%$ believed it to be successful and $35.79 \%$ found it to be very successful. As shown in Fig. 7.3, it is evident that most of the people who knew about the mechanism believed in its efficacy.

\subsubsection{Eighty-Five Percent of the Public Were Satisfied with Prevention and Control Efforts from Their Local Governments}

The public was also satisfied with their local governments, as $85 \%$ were satisfied with their local government's overall performance, but generally not as much as they were satisfied with the central government. As you can see in Fig. 7.4, which shows the public's satisfaction towards the central government, the proportion of people who answered very satisfied declined, and overall satisfaction dropped by $7 \%$, while more people answered as being neutral to not being satisfied with their local government's performance.

In line with the satisfaction found with the central government, demographic factors such as gender, age, educational background, income, and family 
On the overall efficacy of the prevention and control mechanism

\section{$57.09 \%$}

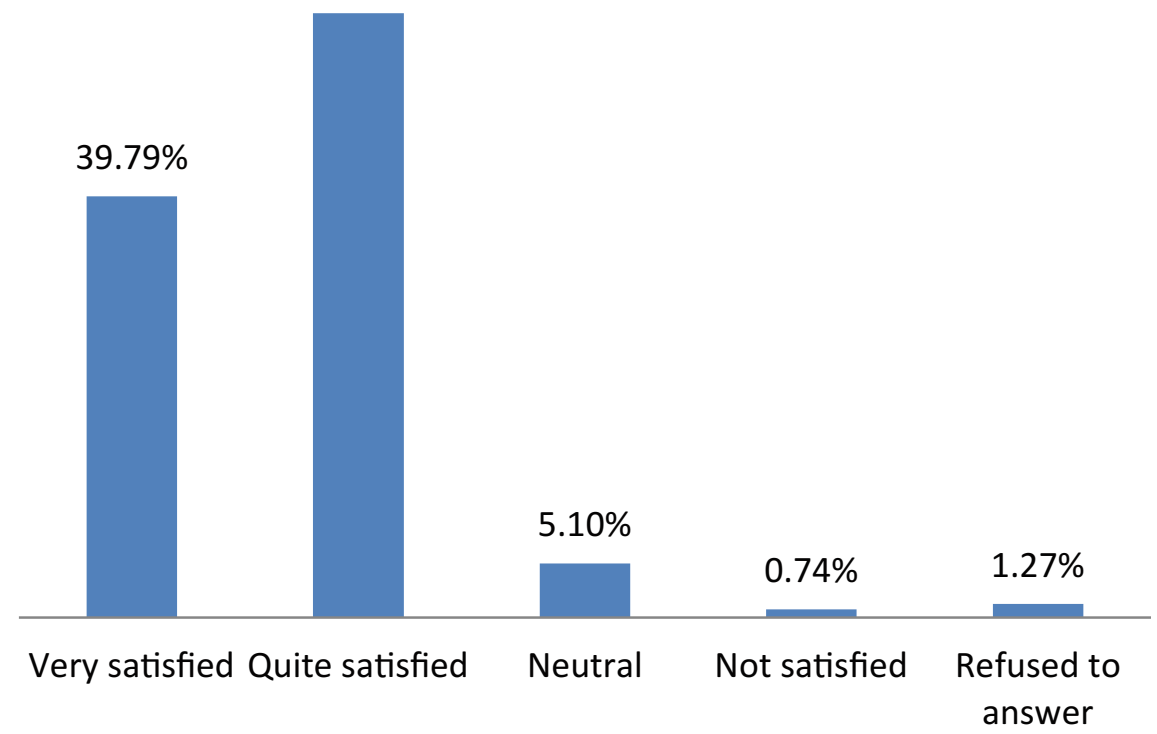

Fig. 7.3 Assessments by respondents aware of the prevention and control mechanism of its efficacy in Influenza A (H1N1) response efforts

Central government $\quad$ Local government

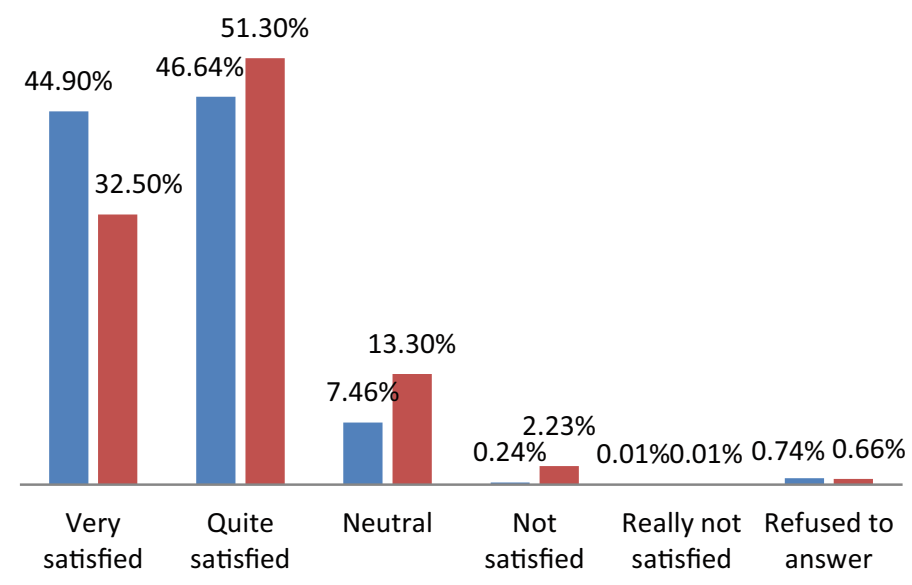

Fig. 7.4 The public's satisfaction in the local government's responses to Influenza A (H1N1) (Unit: \%) background had no significant impact on the level of satisfaction. Occupations, however, did have a relatively significant impact as $12.4 \%$ of service members as well as the same percentage of police officers were neutral or dissatisfied with the 
local government's overall performance. The participants working in education had the highest level of dissatisfaction among the groups, with $9.1 \%$ answering as dissatisfied.

In terms of a regional comparison, residents in the central region were slightly less satisfied with local government than residents in the eastern and western regions, while the proportion of eastern respondents expressing "not very satisfied" with the performance of local governments was higher than those of the central and western regions.

\subsubsection{The Public's Assessment on the Credibility of the Government}

Credibility in a government is a type of soft resource. It's the amount of trust the public has in their state institutions. It's an important guarantee of a government's usefulness and its improvement, and enhancing this credibility is mutually beneficial for both the government and the public. Enhancing credibility can happen through the government proactively improving its performance, or it can happen through communication with the public. Therefore, we took two factors into consideration when assessing the state's prevention and control efforts and their impact on government credibility. One was measuring the level of trust, or change in trust by the public in their government's emergency response capabilities after they experienced the Influenza A (H1N1) outbreak, which showed the impact of the state's emergency management response on the government's credibility. Second was measuring the level of public trust in the information provided by the government which showed the impact of communication on government credibility.

In order to assess credibility in the state's prevention and control efforts, this assessment team measured the change in trust by the public after they experienced the Influenza A (H1N1) in regards to the central and local government's capabilities in emergency management. We also compared the level of trust during the SARS period with this epidemic. The results of the survey showed that the public generally expressed confidence in the government's emergency response capacity, and the public became significantly more trusting of local governments and their capabilities.

\subsubsection{Ninety-Six Percent of the Public Expressed Confidence in the Central Government's Emergency Response Capabilities}

In regards to the central government's emergency response capabilities, the following results were found: $32.3 \%$ of the public polled felt "the same amount of trust as before;" $44.7 \%$ felt they "trusted in the past, and have a little more trust in them now;" $19.1 \%$ felt "no trust in the past, and now there is trust;" and only $2.1 \%$ felt that they did not trust in the central government (see Table 7.1). 
Table 7.1 Public's assessment on the credibility of central and local government's prevention and control efforts

\begin{tabular}{l|l|l|l|l}
\hline & $\begin{array}{l}\text { After Influenza A } \\
\text { (H1N1) (\%) }\end{array}$ & \multicolumn{3}{l}{ Comparison with the time of SARS(\%) } \\
\cline { 2 - 5 } & $\begin{array}{l}\text { Central } \\
\text { government }\end{array}$ & $\begin{array}{l}\text { Local } \\
\text { government }\end{array}$ & $\begin{array}{l}\text { Central } \\
\text { government }\end{array}$ & $\begin{array}{l}\text { Local } \\
\text { government }\end{array}$ \\
\hline Trust even less than before & 0.2 & 0.3 & 0.1 & 0.4 \\
\hline No change: still no trust & 1.9 & 3.8 & 2.1 & 4.2 \\
\hline $\begin{array}{l}\text { No change: same amount of } \\
\text { trust as before }\end{array}$ & 32.3 & 35.9 & 29.3 & 34.0 \\
\hline $\begin{array}{l}\text { Change: no trust before, now } \\
\text { there is trust }\end{array}$ & 19.1 & 30.7 & 22.3 & 29.1 \\
\hline $\begin{array}{l}\text { Change: trust before, but even } \\
\text { more trust now }\end{array}$ & 44.7 & 27.4 & 43.8 & 29.6 \\
\hline $\begin{array}{l}\text { Refused to answer/don't } \\
\text { know }\end{array}$ & 1.8 & 1.9 & 2.4 & 2.7 \\
\hline
\end{tabular}

\subsubsection{Ninety-Four Percent of the Public Expressed Confidence in Their Local Government's Emergency Response Capabilities}

As shown in Table 7.1, in regards to local government's emergency response capabilities, the following results were found: $35.9 \%$ felt "the same amount of trust as before;" $30.6 \%$ felt they "trusted in the past, and have a little more trust in them now;" $27.4 \%$ "felt no trust in the past, and now there is trust;" and only $4.1 \%$ expressed no trust in their local governments, which is two percentage points higher than those who expressed the same for the central government.

\subsubsection{There Was a Relatively High Level of Credibility of the Central Government Along with a Significant Increase in the Credibility of Local Governments}

The central government's credibility has been relatively high in regards to emergency response, with $77 \%$ of respondents expressing they had confidence or even more confidence than before in the government's capabilities. After experiencing the outbreak of Influenza A (H1N1), the ratio of respondents that felt "no trust before, but now there is trust" was much higher for local governments (30.6\% of respondents) than for the central government (19.1\%). Although the credibility of local governments overall was relatively lower, after the outbreak there was a significant increase in the trust in local governments' response capabilities. 


\subsubsection{Government-Released Information Became the Public's Most Trusted News Source}

In the surveys, we asked respondents about the reliability of news from different sources including the central government, local government, experts, grassroots communities, village groups, working units, and news by word of mouth. The results clearly showed that during this epidemic, the public's most trusted news source was still the government, and the trust in the central government was higher than in local governments (as seen in Fig. 7.5).

Similar to the assessment on the public's satisfaction towards their government, demographic factors such as gender, age, educational background, income, family background, and residence had no significant impact on their perception of the government's credibility. What did make a significant impact on the perception of the credibility of the central government was whether the respondent or any of the respondent's family members had been infected in the past by a contagious virus. However, this one factor did not seem to have any significant impact on the respondents' confidence in their local governments.

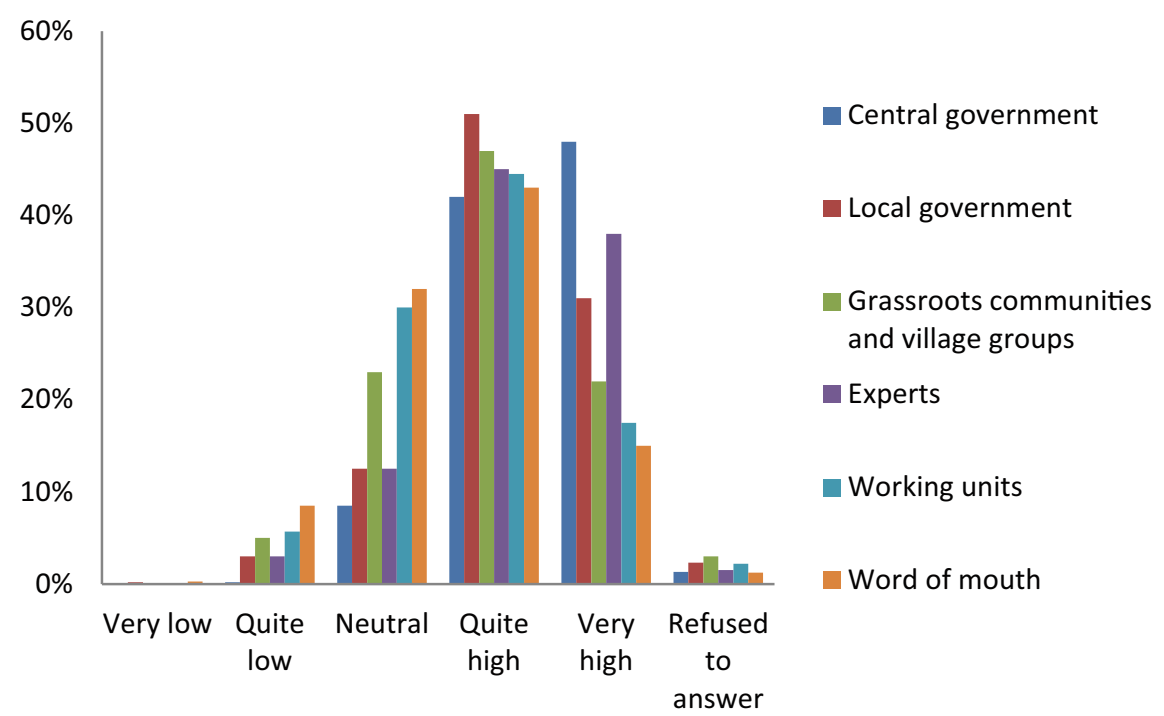

Fig. 7.5 The level of trust the public showed in different news sources (Unit: \%) 


\subsubsection{The Public's Specific Evaluation on the Government's Prevention and Control Measures}

\subsubsection{Over 90\% of the Public Recognized the Necessity for the Prevention and Control Measures}

The government adopted relevant measures in each of the four distinct epidemic phases, and these measures included the following: customs health inspection, patient isolation, close contact isolation, class suspension where the virus was prevalent, the promotion of wearing masks and frequent hand washing, inoculations, more exercise, and the use of traditional Chinese medicine. The majority of the respondents recognized the need for these measures, especially the customs health inspection, patient isolation, close contact isolation, class suspension, and the promotion of exercise. Over half of the respondents felt that these measures were necessary as can be seen in Fig. 7.6. It is clear that there was a wide acceptance by the public of these prevention and control measures and that the implementation personified humanistic care. However, Fig. 7.7 shows that one third of the respondents felt that these measures were inconvenient to a certain extent for their daily routines.

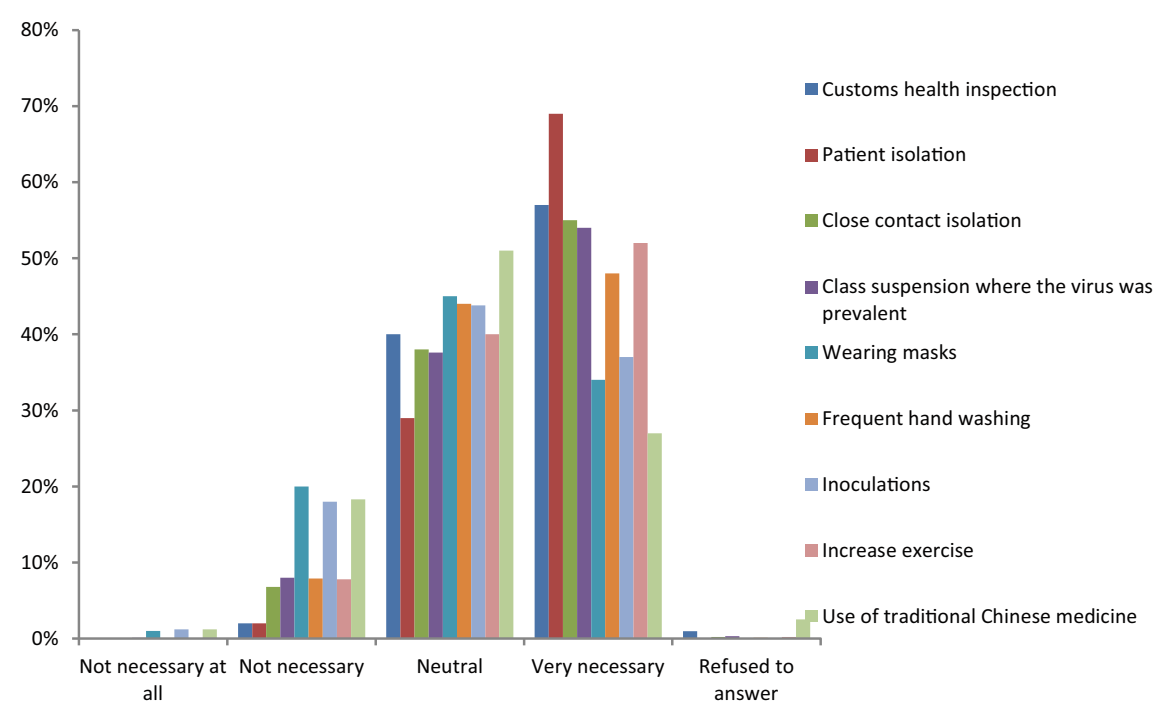

Fig. 7.6 Analysis on the necessity of state-led prevention and control efforts during the four phases of the epidemic 
Influence of the measures on daily lifes, work or school

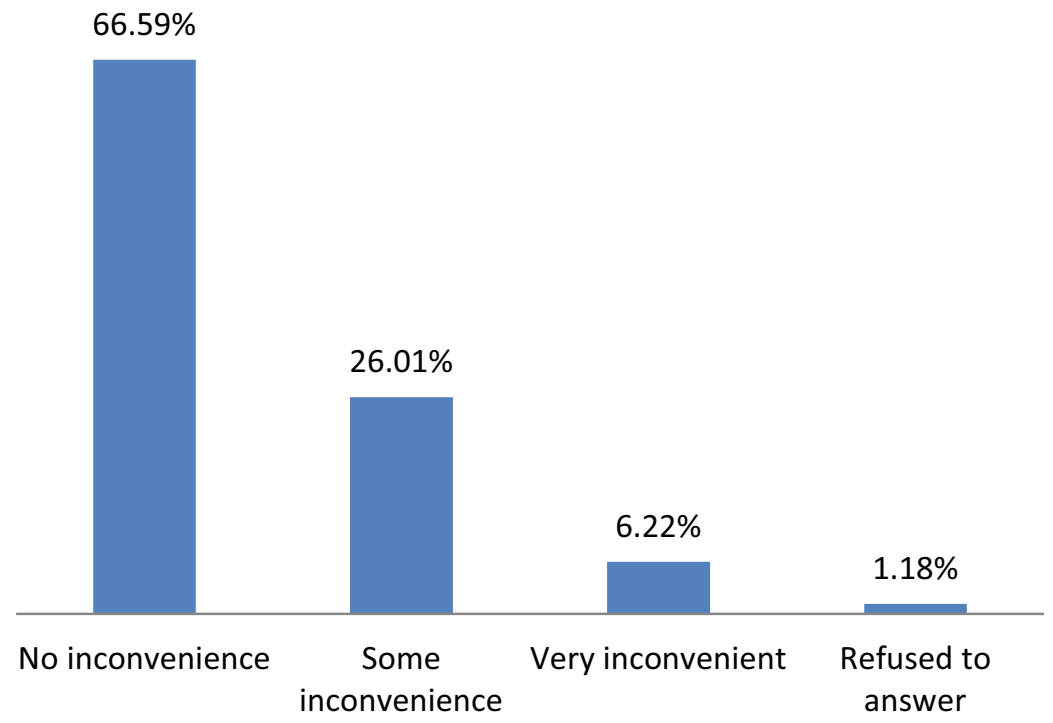

Fig. 7.7 Study on the effects of Influenza A (H1N1) prevention and control measures on daily lives, work, or school

\subsubsection{Nearly Seventy Percent of the Public Recognized the Effective Results of the Prevention and Control Measures}

Close to $70 \%$ of respondents felt that the state-led prevention and control strategies and measures in each of the four phases produced good to very good results, and this sentiment remained consistent throughout all four phases (Fig. 7.8).

\subsubsection{Roughly Fifty Percent of the Public Felt that the Measures Were Appropriate, While About Twenty Percent Felt Them to Be Relatively Strict}

About $50 \%$ of the respondents felt that the measures adopted were appropriate in terms of their intensity, but the ratio of those who felt the measures partially strict did rise in the peak and slow periods of the epidemic (Fig. 7.9).

\subsubsection{Roughly Seventy Percent of the Public Felt that There Were Timely Adjustments to Prevention and Control Strategies}

As seen in Fig. 7.10, 67.9\% of the public felt that the government strategies and measures in place before the first imported case on May 5th were timely; $76.3 \%$ of 


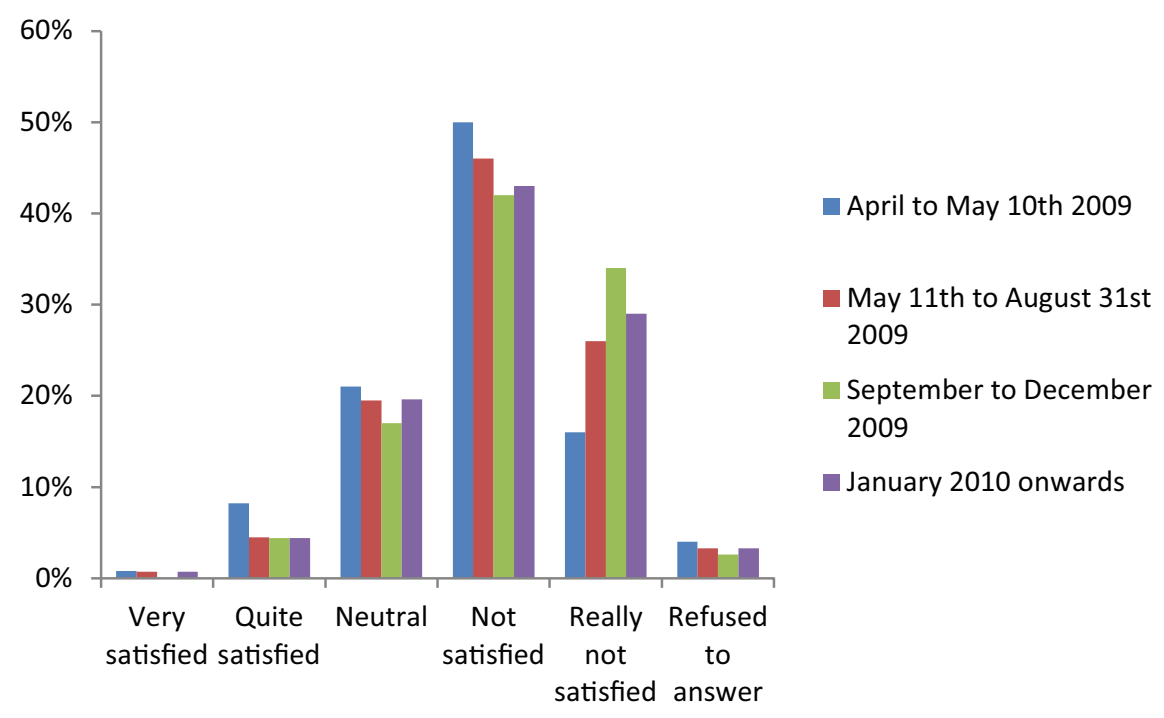

Fig. 7.8 The public's assessment on the results of the state's prevention and control strategies and measures in the four epidemic phases

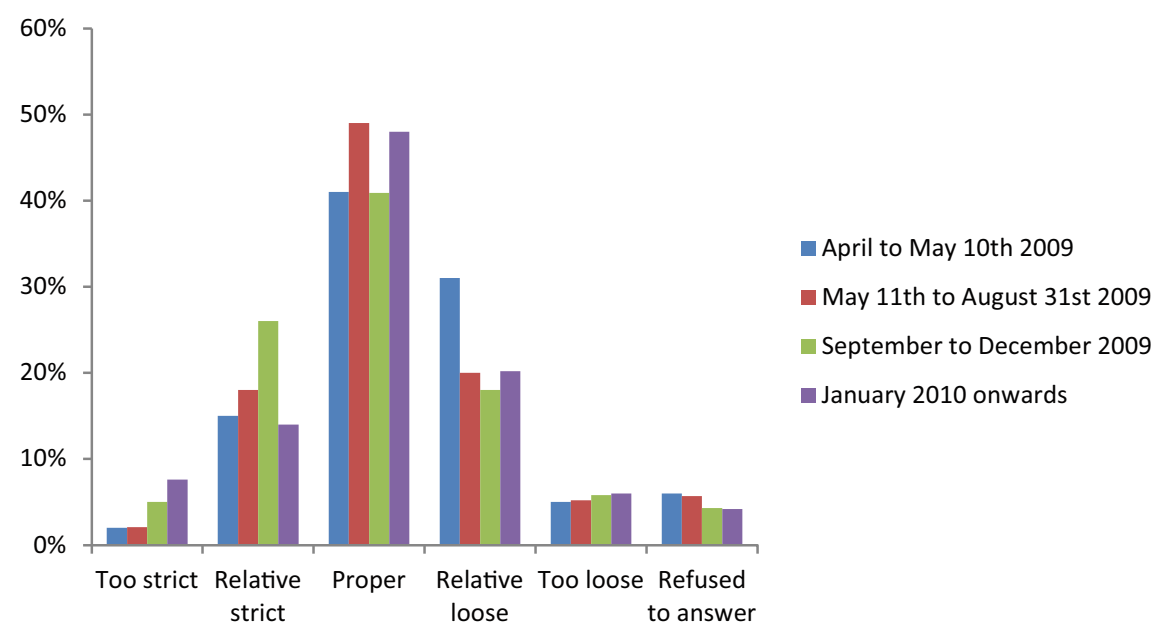

Fig. 7.9 The public's assessment on the overall intensity of prevention and control measures during the four epidemic phases

the public felt that timely adjustments were made to prevention and control measures between May 11th and August 31st; 80.1\% of the public felt that timely adjustments were also made during the epidemic's peak period from September to December 2009; and 75.1\% of the public felt the same after January 2010. 


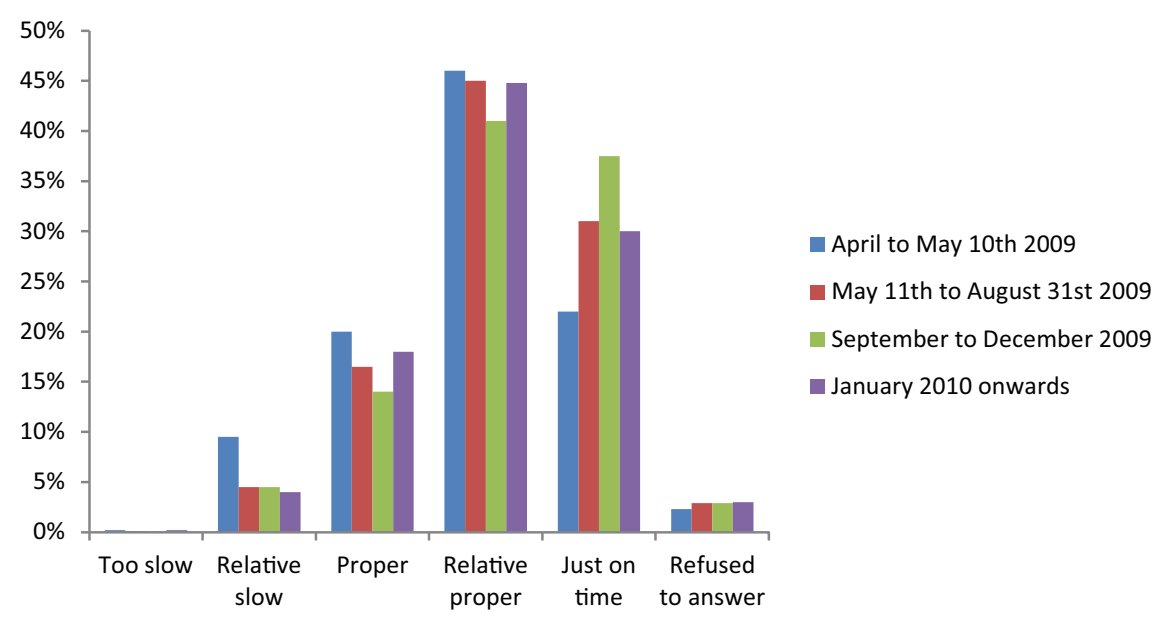

Fig. 7.10 Public's analysis on the timeliness of the prevention and control measures within the four epidemic phases

\subsubsection{Roughly Thirty Percent of the Public Felt that the Government Invested a Lot in Prevention and Control of Influenza A (H1N1)}

As seen in Fig. 7.11, 25.2\% of the public felt that the government invested a lot before the first imported case on May 5th; 29.4\% felt the same for the time period between May 11th and August 31st; 34.9\% for September to December; and 30.5\% for after January 2010.

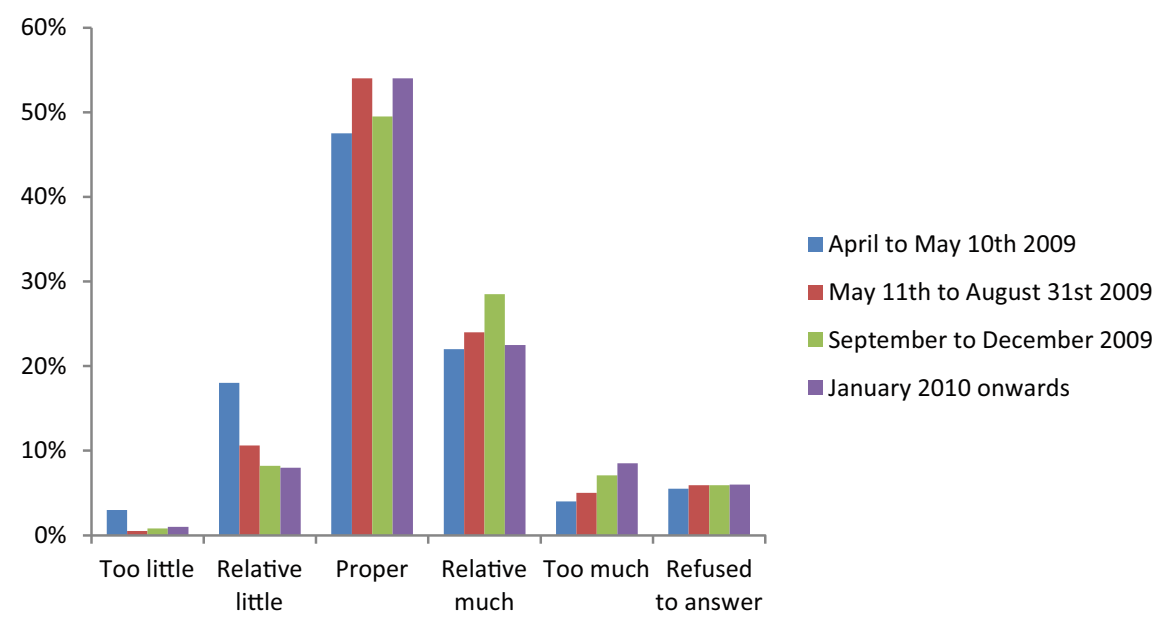

Fig. 7.11 Public's analysis on the government's investment during the four epidemic phases 


\subsubsection{The Public Approved of the Government Disclosing Information Regarding the Epidemic}

Information disclosure to the public had a direct impact on their level of awareness and behaviors surrounding the epidemic. The government disclosed information not only regarding trends in the domestic spread of the virus, and scientific information regarding prevention and control, they also disseminated information on the measures adopted as well as the provided information to relevant agencies.

As seen in Fig. 7.12, the public generally approved of the government's disclosure on epidemic information, and over $80 \%$ of respondents approved of the information regarding their local epidemic situation, the domestic and international trends updates, and the use of self-protection in preventing the spread of the virus. All of those who had been infected with SARS, the Avian Flu, or Influenza A (H1N1) felt that the government did very well in disclosing the right information to the public.

From a regional perspective, people in the eastern regions showed the smallest amount of satisfaction in the local information disclosure regarding the epidemic; the highest level of satisfaction was found in the western regions; and satisfaction in the northern regions was slightly higher than in the southern regions as seen in Figs. 7.13 and 7.14.

\subsubsection{Evaluation of Implementation of Prevention and Control Measures in Key Areas}

Prevention and control in public places was the focal point of post-epidemic measures, which included disinfecting, temperature testing, isolation, prevention and control information dissemination, and the retention of personal data. As

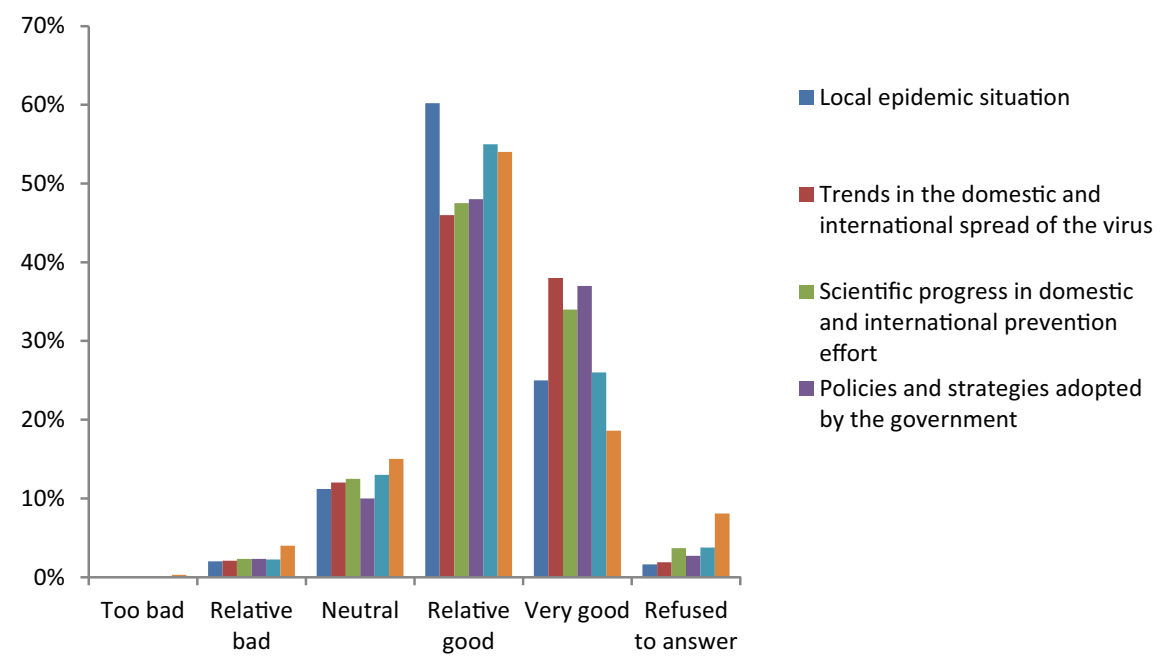

Fig. 7.12 The public's assessment on the government's information disclosure 
Fig. 7.13 Satisfaction in information disclosure in the eastern, middle, and western regions

Fig. 7.14 Satisfaction in information disclosure in the northern and southern regions
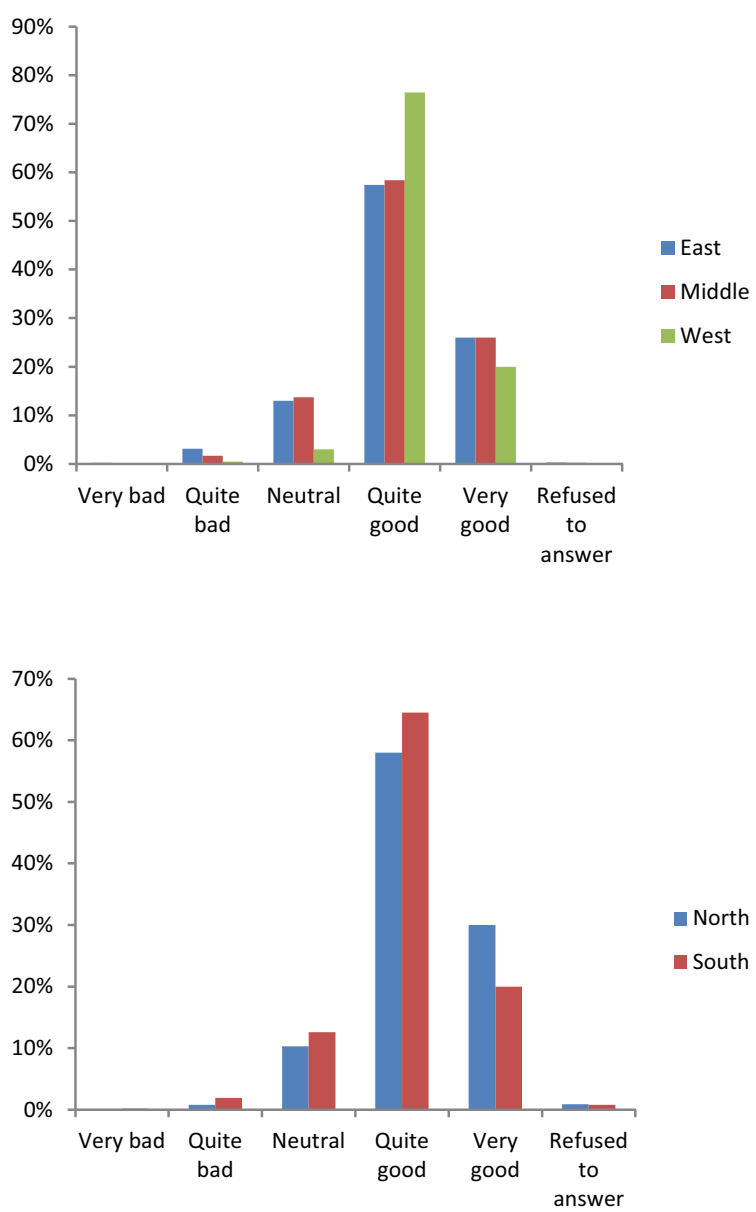

Fig. 7.15 shows, over half of the respondents' communities adopted measures such as disinfecting areas and disseminating prevention and control information, which were the focus of the prevention and control efforts during this phase.

Schools are also focus of the middle- to late-stage prevention and control efforts, and the implementation of these measures was fairly comprehensive. Most schools took measures including disinfecting, temperature testing, as well as prevention and control information dissemination. One third of the schools employed isolation measures and retained personal data (Fig. 7.16).

Hospital-led prevention and control measures were the most comprehensive in scope, as most hospitals adopted measures such as disinfecting, temperature testing, and dissemination of prevention and control information. Almost $40 \%$ of hospitals adopted isolation measures as well (Fig. 7.17). 


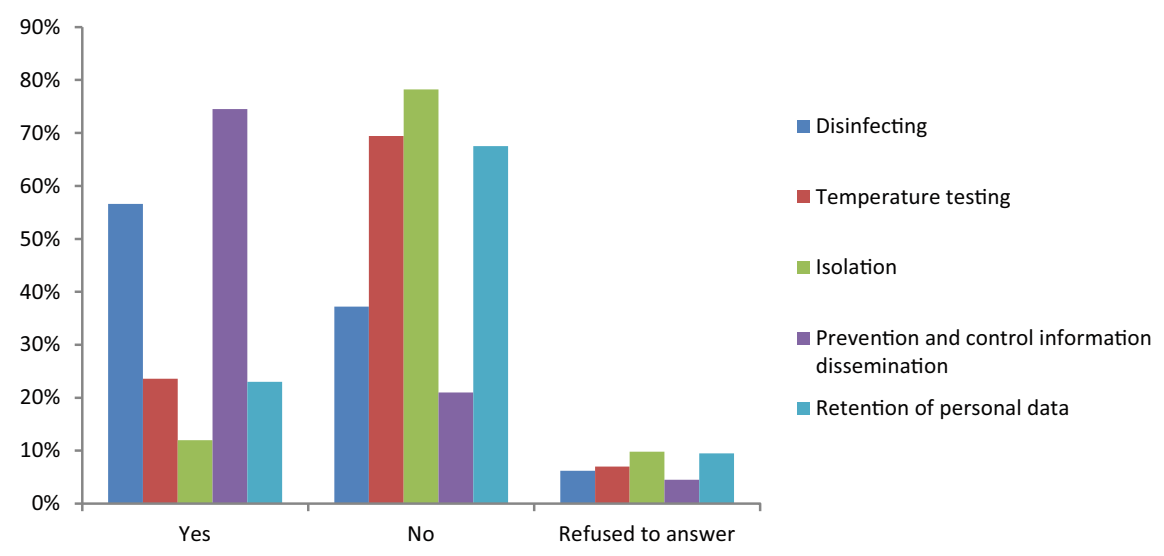

Fig. 7.15 Implementation of community prevention and control measures

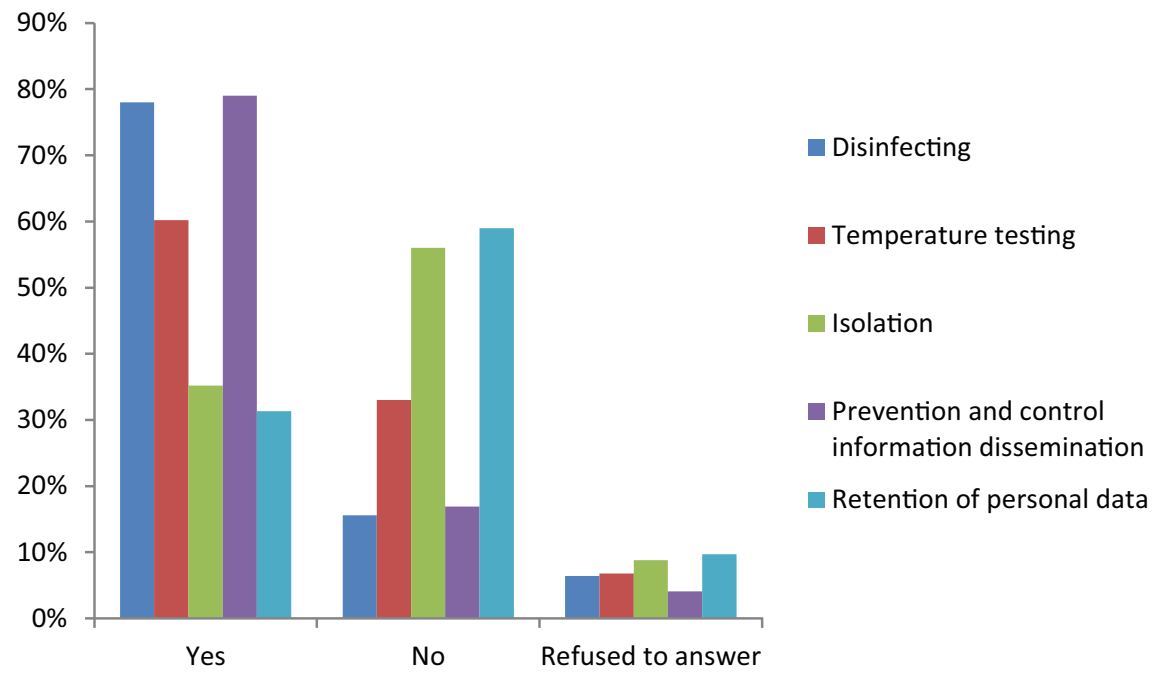

Fig. 7.16 Implementation of school prevention and control measures

A horizontal comparison was done on the same data for different prevention and control measures, and it was found that implementation of disinfecting and temperature testing in schools and hospitals was more comprehensive (Fig. 7.18). As a portion of the respondents lacked any interaction or understanding of hotels, it is understandable that there was a high rate of "refused to answer/don't know" responses. 


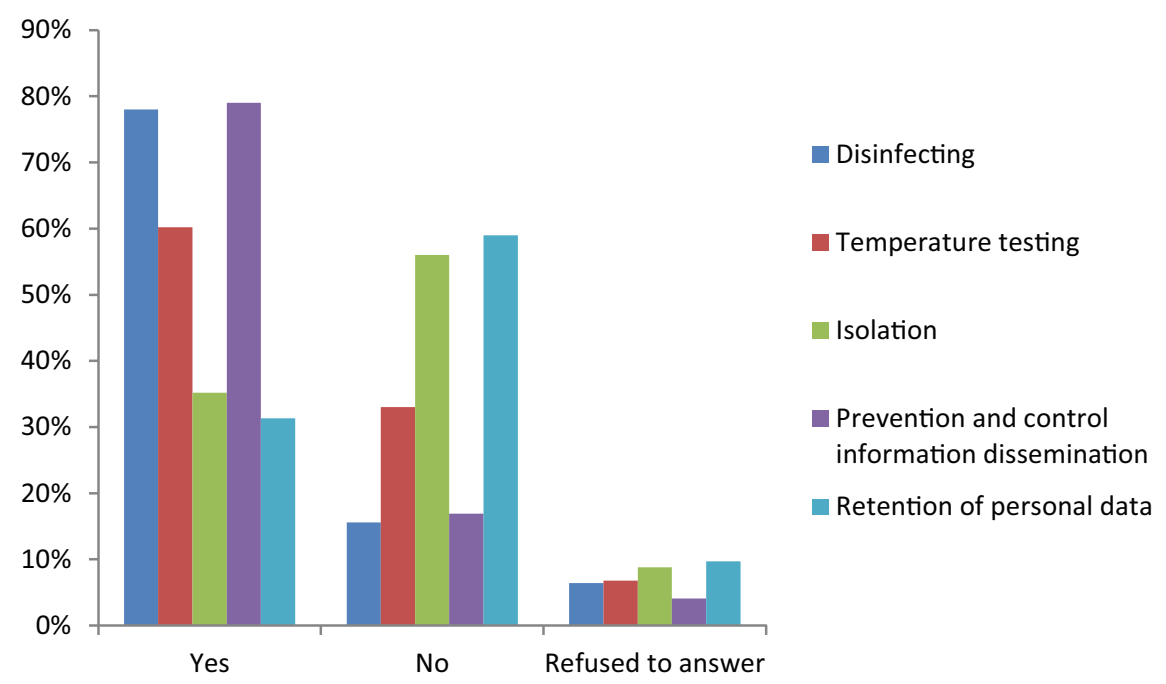

Fig. 7.17 Implementation of hospital prevention and control measures

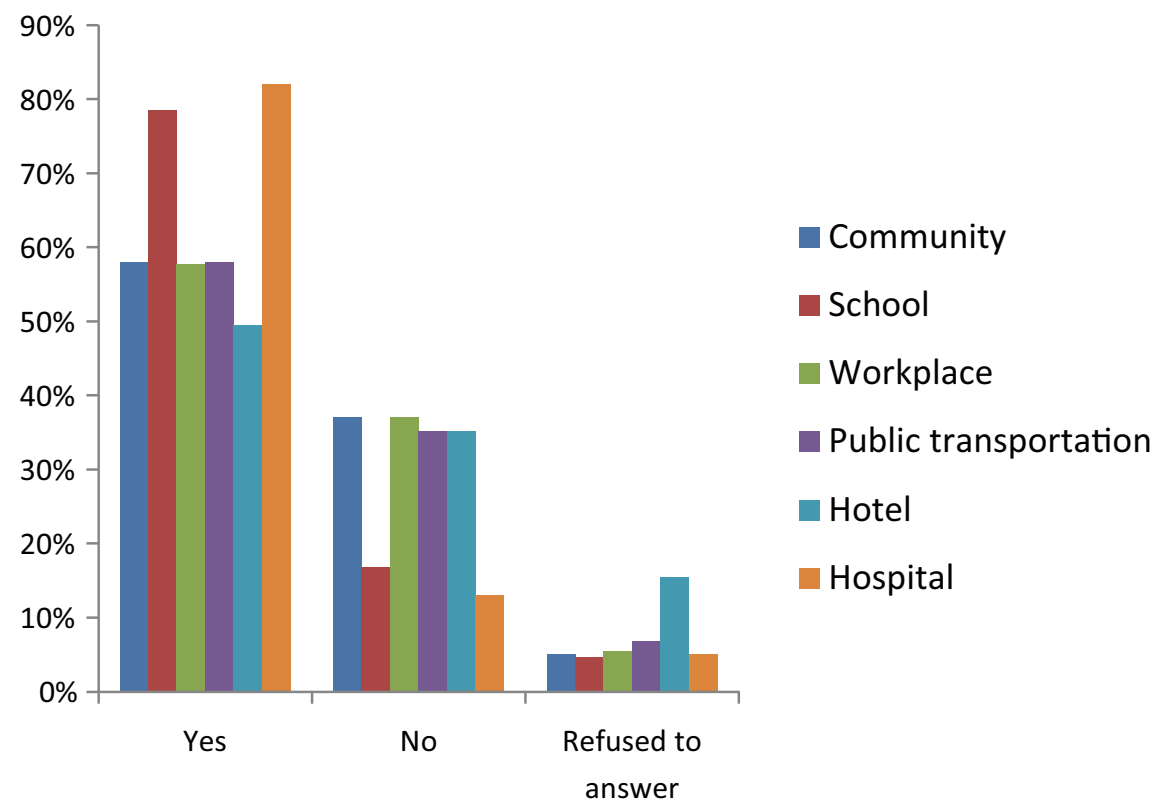

Fig. 7.18 Comparison chart of implemented disinfection measures 


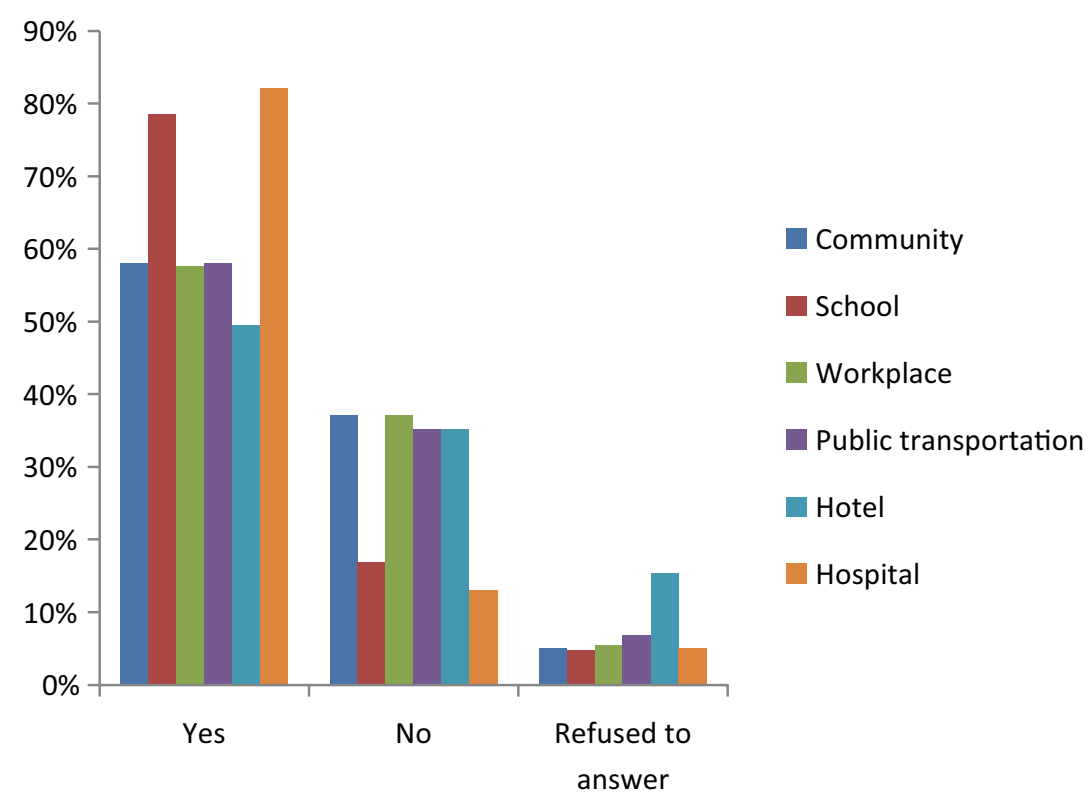

Fig. 7.19 Comparison chart of implemented temperature testing measures

\subsection{Assessments from Influenza A (H1N1) Patients and Close Contacts}

Patients and close contacts of Influenza A (H1N1) were the direct beneficiaries of the state's prevention and control strategies and measures, and their attitudes, feelings, and levels of satisfaction with these policies directly reflect the outcome of the government's response efforts. Understanding the implementation of these prevention and control strategies for patients and close contacts, and understanding the attitudes, feelings, and levels of satisfaction from these affected people towards national strategies, will provide useful references for future emergency response policies. Based on the four different epidemic phases, we employed a stratified sampling method and conducted phone interviews with 893 patients and 646 close contacts from the three areas in the national disease monitoring information report management system: Beijing, Fujian, and Henan. The interview included topics covering implementation of quarantine and treatment policies during different epidemic phases, the implementation of discharge standard policies, the implementation of humanistic care policies, and medical treatment costs. We also investigated the attitudes of the close contacts in regards to medical observation management and humanistic care policy implementation. 


\subsubsection{Assessments from Patients with Influenza A (H1N1)}

\subsubsection{Sixty-Five Percent of Patients Were Satisfied with Prevention and Control Efforts}

The study showed that $65 \%$ of patients were either satisfied or very satisfied with the national prevention and control efforts; $26 \%$ were neutral; and 9\% were dissatisfied or very dissatisfied (Table 7.2).

\subsubsection{Ninety-Three Percent of Patients Found the Prevention and Control Measures Necessary}

As seen in Tables 7.3, 7.4, and 7.5, 93\% of patients felt that the prevention and control measures adopted by the government were necessary; however, $25 \%$ of them felt that these measures caused some level of inconvenience to their daily lives, and among them $79 \%$ felt that they could tolerate this inconvenience. Among those patients who believed the measures were inconvenient, most $(75 \%)$ found the isolation measures to be the most inconvenient, followed by triage, diagnosis, and treatment measures. Lastly, measures such as control of public opinion, information disclosures, and class suspensions did have a certain impact on people's daily lives.

Table 7.2 Influenza A (H1N1) patients' satisfaction assessments with prevention and control efforts

\begin{tabular}{l|l|l|l|l|l|l}
\hline Province & N & Very dissatisfied & Dissatisfied & Neutral & Satisfied & Very satisfied \\
\hline Beijing & 306 & $15(5 \%)$ & $5(2 \%)$ & $77(25 \%)$ & $140(46 \%)$ & $69(22 \%)$ \\
\hline Fujian & 288 & $9(3 \%)$ & $20(7 \%)$ & $82(28 \%)$ & $95(34 \%)$ & $82(28 \%)$ \\
\hline Henan & 299 & $10(3 \%)$ & $24(8 \%)$ & $75(25 \%)$ & $122(41 \%)$ & $68(23 \%)$ \\
\hline Total & 893 & $34(4 \%)$ & $49(5 \%)$ & $234(26 \%)$ & $357(40 \%)$ & $219(25 \%)$ \\
\hline
\end{tabular}

Table 7.3 Influenza A (H1N1) patients' assessment on the necessity of prevention and control measures

\begin{tabular}{l|l|l|l}
\hline Province & N & \multicolumn{2}{|l}{$\begin{array}{l}\text { The necessity in adopting } \\
\text { prevention and control measures } \\
\text { against Influenza A (H1N1) }\end{array}$} \\
\cline { 3 - 4 } & & Yes & No \\
\hline Beijing & 306 & $278(91 \%)$ & $28(9 \%)$ \\
\hline Fujian & 287 & $272(95 \%)$ & $15(5 \%)$ \\
\hline Henan & 293 & $272(93 \%)$ & $21(7 \%)$ \\
\hline Total & 886 & $822(93 \%)$ & $64(7 \%)$ \\
\hline
\end{tabular}


Table 7.4 Influenza A (H1N1) patients' assessment on convenience of prevention and control measures

\begin{tabular}{l|l|l|l|l}
\hline \multirow{2}{*}{ Province } & \multirow{2}{*}{$\mathrm{N}$} & \multicolumn{3}{|l}{$\begin{array}{l}\text { Did the national prevention and control measures } \\
\text { cause any inconvenience? }\end{array}$} \\
\cline { 3 - 5 } & & Yes & No & Hard to say \\
\hline Beijing & 303 & $76(25 \%)$ & $185(61 \%)$ & $42(14 \%)$ \\
\hline Fujian & 288 & $65(23 \%)$ & $206(72 \%)$ & $17(6 \%)$ \\
\hline Henan & 298 & $79(27 \%)$ & $212(71 \%)$ & $7(2 \%)$ \\
\hline Total & 889 & $220(25 \%)$ & $603(68 \%)$ & $66(7 \%)$ \\
\hline
\end{tabular}

Table 7.5 Evaluation of the tolerance for inconvenience of Influenza A (H1N1) patients

\begin{tabular}{l|l|l|l}
\hline \multirow{2}{*}{ Province } & \multirow{N}{*}{} & \multicolumn{3}{|l}{ Toleration for inconvenience } \\
\cline { 3 - 4 } & & Can & Cannot \\
\hline Beijing & 76 & $57(75 \%)$ & $19(25 \%)$ \\
\hline Fujian & 65 & $50(77 \%)$ & $15(23 \%)$ \\
\hline Henan & 79 & $66(84 \%)$ & $13(16 \%)$ \\
\hline Total & 220 & $173(79 \%)$ & $47(21 \%)$ \\
\hline
\end{tabular}

\subsubsection{Fifty-Seven Percent of Patients Felt that the Prevention and Control Measures Were Appropriate}

Table 7.6 shows that $17 \%$ of patients felt that state-led prevention and control measures were a little strict during the onset of the epidemic. During our investigations into assessments of early prevention and control, we discovered that respondents in in the central province of Henan felt that these measures were a little strict and it also was evident that there was a certain rationality and necessity to adjusting regional policies according to regional differences.

Table 7.7 shows that $42 \%$ of patients felt that the prevention and control measures taken against the Influenza A (H1N1) epidemic were fair or very fair; 37\% were neutral; $13 \%$ felt it was hard to say; and $7 \%$ felt that they were unfair or very unfair. Among those, respondents' overall evaluations in Henan were lower than those found in Beijing and Fujian, and thus it is clear that distinct differences existed in the implementation and adjustments of regional policies.

Table 7.6 Influenza A (H1N1) patient's evaluation on the adequacy of early prevention and control measures

\begin{tabular}{l|l|l|l|l|l}
\hline Province & \multirow{2}{*}{$\mathrm{N}$} & \multicolumn{4}{|l}{ The adequacy of early prevention and control measures } \\
\cline { 3 - 6 } & & Relatively strict & Relatively relaxed & Appropriate & Hard to say \\
\hline Beijing & 306 & $50(16 \%)$ & $29(9 \%)$ & $159(52 \%)$ & $68(22 \%)$ \\
\hline Fujian & 287 & $50(17 \%)$ & $26(9 \%)$ & $173(60 \%)$ & $38(13 \%)$ \\
\hline Henan & 298 & $50(7 \%)$ & $29(10 \%)$ & $176(59 \%)$ & $43(14 \%)$ \\
\hline Total & 891 & $150(17 \%)$ & $84(9 \%)$ & $508(57 \%)$ & $149(17 \%)$ \\
\hline
\end{tabular}


Table 7.7 Influenza A (H1N1) patients' assessment on the fairness of the prevention and control measures

\begin{tabular}{l|l|l|l|l|l|l|l}
\hline Province & \multirow{2}{*}{ N } & \multicolumn{6}{|l}{ Fairness in Influenza A (H1N1) prevention and control measures } \\
\cline { 3 - 8 } & & $\begin{array}{l}\text { Very } \\
\text { unfair }\end{array}$ & $\begin{array}{l}\text { Somewhat } \\
\text { unfair }\end{array}$ & Neutral & $\begin{array}{l}\text { Somewhat } \\
\text { fair }\end{array}$ & $\begin{array}{l}\text { Very } \\
\text { fair }\end{array}$ & $\begin{array}{l}\text { Hard to } \\
\text { say }\end{array}$ \\
\hline Beijing & 306 & $4(1 \%)$ & $4(1 \%)$ & $92(30 \%)$ & $77(25 \%)$ & $89(29 \%)$ & $40(13 \%)$ \\
\hline Fujian & 286 & $5(2 \%)$ & $15(5 \%)$ & $75(26 \%)$ & $107(37 \%)$ & $36(13 \%)$ & $48(17 \%)$ \\
\hline Henan & 297 & $5(2 \%)$ & $31(10 \%)$ & $163(55 \%)$ & $49(16 \%)$ & $17(6 \%)$ & $32(11 \%)$ \\
\hline Total & 889 & $14(2 \%)$ & $50(5 \%)$ & $330(37 \%)$ & $233(26 \%)$ & $\begin{array}{l}142 \\
(16 \%)\end{array}$ & $\begin{array}{l}120 \\
(13 \%)\end{array}$ \\
\hline
\end{tabular}

\subsubsection{Eighty-Four Percent of Patients Felt that the State's Investment into Influenza A (H1N1) Prevention and Control Was Worth It}

In regards to investment into prevention and control efforts, Table 7.8 shows that $84 \%$ of patients felt that the cost of these measures was worth it. It is clear that state investments into the prevention and control measure were widely supported and accepted by patients.

\subsubsection{Eighty-Two Percent of Patients Felt that Progress Was Made in the State's Public Emergency Response Capabilities}

In addition to SARS, the Influenza A (H1N1) pandemic was another test in global public health emergency management. In comparison with SARS, $82 \%$ of Influenza A (H1N1) patients felt that the government had made improvements in its public health emergency response capabilities. Among those, Beijing had the highest number of respondents (87\%) who felt that progress had been made (Table 7.9).

Table 7.10 shows that after experiencing the prevention and control, $79 \%$ of patients felt they could trust in the government's response capabilities; $15 \%$ stated it was hard to say; and $6 \%$ expressed distrust in the government's capabilities.

Table 7.8 Influenza A (H1N1) patients' assessment on the necessity of state investment in prevention and control measures

\begin{tabular}{l|l|l|l|l|l}
\hline Province & N & \multicolumn{4}{l}{$\begin{array}{l}\text { Necessity of state investment into prevention and control } \\
\text { measures }\end{array}$} \\
\cline { 3 - 6 } & & Worth it & Not worth it & Neutral & Hard to say \\
\hline Beijing & 307 & $250(81 \%)$ & $11(4 \%)$ & $18(6 \%)$ & $28(9 \%)$ \\
\hline Fujian & 289 & $250(86 \%)$ & $3(1 \%)$ & $10(3 \%)$ & $26(9 \%)$ \\
\hline Henan & 297 & $253(85 \%)$ & $10(3 \%)$ & $12(4 \%)$ & $22(7 \%)$ \\
\hline Total & 893 & $753(84 \%)$ & $24(3 \%)$ & $40(4 \%)$ & $76(9 \%)$ \\
\hline
\end{tabular}


Table 7.9 Influenza A (H1N1) patient's assessment in public health emergency response capabilities

\begin{tabular}{l|l|l|l|l|l|l}
\hline Province & \multirow{2}{*}{} & \multicolumn{5}{|l}{ Progress in response capabilities since SARS } \\
\cline { 3 - 7 } & $\begin{array}{l}\text { A lot of } \\
\text { progress }\end{array}$ & $\begin{array}{l}\text { Some } \\
\text { progress }\end{array}$ & $\begin{array}{l}\text { No } \\
\text { progress }\end{array}$ & $\begin{array}{l}\text { Some } \\
\text { regression }\end{array}$ & $\begin{array}{l}\text { A lot of } \\
\text { regression }\end{array}$ \\
\hline Beijing & 305 & $71(23 \%)$ & $195(64 \%)$ & $31(10 \%)$ & $6(2 \%)$ & $2(1 \%)$ \\
\hline Fujian & 287 & $38(13 \%)$ & $194(68 \%)$ & $24(8 \%)$ & $28(10 \%)$ & $3(1 \%)$ \\
\hline Henan & 299 & $36(12 \%)$ & $197(66 \%)$ & $56(19 \%)$ & $8(3 \%)$ & $2(1 \%)$ \\
\hline Total & 891 & $145(16 \%)$ & $586(66 \%)$ & $111(12 \%)$ & $42(5 \%)$ & $7(1 \%)$ \\
\hline
\end{tabular}

Table 7.10 Assessment of trust in emergency response after the outbreak of Influenza A (H1N1)

\begin{tabular}{l|l|l|l|l}
\hline \multirow{2}{*}{ Province } & \multirow{4}{*}{ N } & \multicolumn{3}{l}{$\begin{array}{l}\text { Trust in state emergency response capabilities after } \\
\text { Influenza A (H1N1) outbreak }\end{array}$} \\
\cline { 3 - 5 } & & Yes & No & Hard to say \\
\hline Beijing & 306 & $236(77 \%)$ & $16(5 \%)$ & $54(18 \%)$ \\
\hline Fujian & 288 & $227(79 \%)$ & $16(6 \%)$ & $45(16 \%)$ \\
\hline Henan & 285 & $230(81 \%)$ & $25(9 \%)$ & $30(11 \%)$ \\
\hline Total & 879 & $693(79 \%)$ & $57(6 \%)$ & $129(15 \%)$ \\
\hline
\end{tabular}

Table 7.11 Close contacts' satisfaction assessments with prevention and control efforts

\begin{tabular}{l|l|l|l|l|l|l}
\hline Province & $\mathrm{N}$ & Very dissatisfied & Dissatisfied & Neutral & Satisfied & Very satisfied \\
\hline Beijing & 247 & $2(1 \%)$ & $1(0 \%)$ & $27(11 \%)$ & $125(51 \%)$ & $92(37 \%)$ \\
\hline Fujian & 198 & $5(3 \%)$ & $0(0 \%)$ & $38(19 \%)$ & $97(49 \%)$ & $58(29 \%)$ \\
\hline Henan & 199 & $2(1 \%)$ & $2(1 \%)$ & $26(13 \%)$ & $77(39 \%)$ & $92(46 \%)$ \\
\hline Total & 644 & $9(1 \%)$ & $3(0 \%)$ & $91(14 \%)$ & $299(46 \%)$ & $242(38 \%)$ \\
\hline
\end{tabular}

\subsubsection{Assessments from Close Contacts of Influenza A (H1N1)}

\subsubsection{Eighty-Four Percent of Close Contacts Expressed Satisfaction in Prevention and Control Efforts}

Our research discovered that $84 \%$ of close contacts felt satisfied or very satisfied with the state's prevention and control efforts against Influenza A (H1N1); 14\% were neutral; and $2 \%$ felt dissatisfied or very dissatisfied. 


\subsubsection{Ninety-Three Percent of Close Contacts Felt that the Prevention and Control Efforts Were Necessary}

As seen in Tables 7.12, 7.13, and 7.14, 93\% of close contacts polled felt that the prevention and control measures directed towards them were necessary, but $23 \%$ of them also felt that these efforts caused to some extent inconvenience to their daily lives. Among those that felt inconvenienced, $92 \%$ of them felt they could tolerate it.

\subsubsection{Seventy-One Percent of Close Contacts Felt that the Prevention and Control Measures Were Appropriate}

Regarding the prevention and control measures adopted by the government at the start of the epidemic, $11 \%$ of close contacts felt that they were a little strict; $71 \%$ felt them to be appropriate; only $3 \%$ found them to be too relaxed; and $15 \%$ stated it

Table 7.12 Close contacts' assessment on the necessity of prevention and control measures

Table 7.13 Close contacts' assessment on convenience of prevention and control measures

Table 7.14 Evaluation of the tolerance for inconvenience of close contacts

\begin{tabular}{l|l|l|l}
\hline Province & N & \multicolumn{2}{|l}{$\begin{array}{l}\text { The necessity of prevention } \\
\text { and control measures } \\
\text { directed towards close } \\
\text { contacts }\end{array}$} \\
\cline { 3 - 4 } & & Yes & No \\
\hline Beijing & 248 & $224(90 \%)$ & $24(10 \%)$ \\
\hline Fujian & 199 & $188(94 \%)$ & $11(6 \%)$ \\
\hline Henan & 199 & $191(96 \%)$ & $8(4 \%)$ \\
\hline Total & 646 & $603(93 \%)$ & $43(7 \%)$ \\
\hline
\end{tabular}

\begin{tabular}{l|l|l|l|l}
\hline Province & \multirow{2}{*}{} & \multicolumn{4}{|l}{$\begin{array}{l}\text { Did the national prevention and control } \\
\text { measures directed towards close contacts } \\
\text { cause any inconvenience? }\end{array}$} \\
\cline { 3 - 5 } & & Yes & No & Hard to say \\
\hline Beijing & 248 & $70(28 \%)$ & $147(59 \%)$ & $31(13 \%)$ \\
\hline Fujian & 199 & $38(19 \%)$ & $156(78 \%)$ & $5(3 \%)$ \\
\hline Henan & 198 & $40(20 \%)$ & $158(80 \%)$ & $0(0 \%)$ \\
\hline Total & 645 & $148(23 \%)$ & $461(71 \%)$ & $36(6 \%)$ \\
\hline
\end{tabular}

\begin{tabular}{l|l|l|l}
\hline Province & \multirow{2}{*}{} & \multicolumn{2}{|l}{$\begin{array}{l}\text { Is the inconvenience } \\
\text { tolerable? }\end{array}$} \\
\cline { 3 - 4 } & & Yes & No \\
\hline Beijing & 69 & $60(87 \%)$ & $9(13 \%)$ \\
\hline Fujian & 28 & $27(27 \%)$ & $1(4 \%)$ \\
\hline Henan & 35 & $34(97 \%)$ & $1(3 \%)$ \\
\hline Total & 132 & $121(92 \%)$ & $11(8 \%)$ \\
\hline
\end{tabular}


Table 7.15 Close contacts' evaluation on the adequacy of early prevention and control measures

\begin{tabular}{l|l|l|l|l|l}
\hline Province & \multirow{2}{*}{$\begin{array}{l}\text { N } \\
\text { The adequacy of prevention and control measures adopted at the start of } \\
\text { the epidemic }\end{array}$} \\
\cline { 3 - 6 } & & Relatively strict & Relatively relaxed & Appropriate & Hard to say \\
\hline Beijing & 248 & $40(16 \%)$ & $9(4 \%)$ & $166(67 \%)$ & $33(13 \%)$ \\
\hline Fujian & 199 & $8(4 \%)$ & $10(5 \%)$ & $130(65 \%)$ & $51(26 \%)$ \\
\hline Henan & 197 & $21(11 \%)$ & $3(2 \%)$ & $161(82 \%)$ & $12(6 \%)$ \\
\hline Total & 644 & $69(11 \%)$ & $22(3 \%)$ & $457(71 \%)$ & $96(15 \%)$ \\
\hline
\end{tabular}

Table 7.16 Close contacts' evaluation on the fairness of prevention and control measures

\begin{tabular}{l|l|l|l|l|l|l|l}
\hline Province & \multirow{2}{*}{$\mathrm{N}$} & \multicolumn{6}{l}{ Fairness in prevention and control measures } \\
\cline { 3 - 8 } & & Very unfair & Unfair & Neutral & Fair & Very fair & Hard to say \\
\hline Beijing & 247 & $3(1 \%)$ & $4(2 \%)$ & $38(15 \%)$ & $92(37 \%)$ & $85(34 \%)$ & $25(10 \%)$ \\
\hline Fujian & 199 & $0(0 \%)$ & $6(3 \%)$ & $49(25 \%)$ & $88(44 \%)$ & $13(7 \%)$ & $43(22 \%)$ \\
\hline Henan & 198 & $1(1 \%)$ & $5(3 \%)$ & $101(51 \%)$ & $79(40 \%)$ & $4(2 \%)$ & $8(4 \%)$ \\
\hline Total & 644 & $4(1 \%)$ & $15(2 \%)$ & $188(29 \%)$ & $259(40 \%)$ & $102(16 \%)$ & $76(12 \%)$ \\
\hline
\end{tabular}

was hard to say. Also, $56 \%$ of close contacts felt that the prevention and control measures adopted were fair or very fair, and only $3 \%$ felt that they were unfair (Tables 7.15 and 7.16).

\subsubsection{Eighty-Two Percent of Close Contacts Felt that the State Investment into Influenza A (H1N1) Prevention and Control Was Worth It}

Among the close contacts, $82 \%$ felt that the state investment into Influenza A (H1N1) prevention and control was worth it, while only $3 \%$ felt it was not (Table 7.17).

Table 7.17 Close contacts' approval assessment on the state investment in prevention and control measures

\begin{tabular}{l|l|l|l|l|l}
\hline \multirow{2}{*}{ Province } & \multirow{2}{*}{$\mathrm{N}$} & \multicolumn{4}{|l}{ The worthiness of the cost of state prevention and control efforts } \\
\cline { 3 - 6 } & & Worth it & Not worth it & Neutral & Hard to say \\
\hline Beijing & 248 & $180(73 \%)$ & $15(6 \%)$ & $23(9 \%)$ & $30(12 \%)$ \\
\hline Fujian & 199 & $170(85 \%)$ & $4(2 \%)$ & $6(3 \%)$ & $19(10 \%)$ \\
\hline Henan & 199 & $177(89 \%)$ & $3(2 \%)$ & $9(5 \%)$ & $10(5 \%)$ \\
\hline Total & 646 & $527(82 \%)$ & $22(3 \%)$ & $38(6 \%)$ & $59(9 \%)$ \\
\hline
\end{tabular}




\subsubsection{Ninety-Five Percent of Close Contacts Felt that the State Had Made Progress in Their Public Health Emergency Response Capabilities}

In comparison with the response to SARS, 95\% of close contacts felt that the state had made progress in its public health emergency response capabilities (as seen in Table 7.18).

After experiencing the prevention and control measures against the Influenza A (H1N1) epidemic, $84 \%$ of close contacts felt they could trust the state's health emergency response capabilities; $15 \%$ stated it was hard to say; and $6 \%$ expressed distrust as seen in Table 7.19.

\subsection{Assessments from Medical Personnel and Agencies}

Medical agencies and disease prevention and control mechanisms were the core organizations in the response efforts against Influenza A (H1N1), as they were responsible for policy advice and implementation during the epidemic. Thus, medical personnel working for these agencies were directly involved in the process and should be able to make judgments concerning these policies. Their assessments on the timeliness, necessity, rationality, feasibility, sustainability, and comprehensiveness of these policies will better reflect the implementation and effects of these policies and measures. In order to gain an understanding of assessments from

Table 7.18 Close contacts' approval assessment of progress made in response measures since SARS

\begin{tabular}{l|l|l|l|l|l|l}
\hline Province & \multirow{2}{*}{} & \multicolumn{6}{|l}{ Progress in response capabilities since SARS } \\
\cline { 3 - 7 } & & $\begin{array}{l}\text { A lot of } \\
\text { progress }\end{array}$ & $\begin{array}{l}\text { Some } \\
\text { progress }\end{array}$ & $\begin{array}{l}\text { No } \\
\text { progress }\end{array}$ & $\begin{array}{l}\text { Some } \\
\text { regression }\end{array}$ & $\begin{array}{l}\text { A lot of } \\
\text { regression }\end{array}$ \\
\hline Beijing & 246 & $105(43 \%)$ & $131(53 \%)$ & $7(3 \%)$ & $0(0 \%)$ & $3(1 \%)$ \\
\hline Fujian & 197 & $25(13 \%)$ & $162(82 \%)$ & $6(3 \%)$ & $0(0 \%)$ & $4(2 \%)$ \\
\hline Henan & 199 & $42(21 \%)$ & $141(71 \%)$ & $16(8 \%)$ & $0(0 \%)$ & $0(0 \%)$ \\
\hline Total & 642 & $172(27 \%)$ & $434(67 \%)$ & $29(5 \%)$ & $0(0 \%)$ & $7(1 \%)$ \\
\hline
\end{tabular}

Table 7.19 Close contacts' evaluation of health emergency response capabilities after Influenza A (H1N1)

\begin{tabular}{|c|c|c|c|c|}
\hline \multirow[t]{2}{*}{ Province } & \multirow[t]{2}{*}{$\mathrm{N}$} & \multicolumn{3}{|c|}{$\begin{array}{l}\text { Trust in state's emergency response } \\
\text { capabilities after Influenza A (H1N1) }\end{array}$} \\
\hline & & Trust & Don't trust & Hard to say \\
\hline Beijing & 248 & $212(85 \%)$ & $4(2 \%)$ & $32(13 \%)$ \\
\hline Fujian & 199 & $141(71 \%)$ & $6(3 \%)$ & $52(26 \%)$ \\
\hline Henan & 197 & 191(97\%) & $1(1 \%)$ & $5(3 \%)$ \\
\hline Total & 644 & $544(84 \%)$ & $11(2 \%)$ & $89(14 \%)$ \\
\hline
\end{tabular}


medical personnel on national prevention and control policies, we provided a questionnaire to the following entities: the heads of the comprehensive team, the medical treatment team, and the safeguarding team from the Prevention and Control Mechanism; managers and leaders from 29 designated hospitals for Influenza A (H1N1) cases and hospitals that received and treated severe cases of Influenza A (H1N1); and relevant personnel from 31 disease prevention and control agencies all within Beijing, Fujian, Guangdong, Sichuan, and Henan. The questionnaire covered the evaluation and analysis for medical agencies and disease prevention and control departments on the distribution, adjustments, implementation, and enforceability of national medical treatment policies.

\subsubsection{Assessments from Medical Agency Personnel}

Tables 7.20, 7.21, and 7.22 display the scores given to prevention and control policies and medical policy implementation by medical personnel in the 29 designated hospitals that treated Influenza A (H1N1). These personnel assessed the policies' timeliness, necessity, rationality, feasibility, sustainability, and comprehensiveness.

Table 7.20 Assessments by medical personnel in key hospitals on early prevention and control policies and plans for the phase with mostly imported cases $(n=243)$

\begin{tabular}{l|l|l|l|l|l|l}
\hline Score & Timeliness & Necessity & Rationality & Feasibility & Sustainability & Comprehensiveness \\
\hline 1 & 0 & 0 & 0 & 0 & 2 & 0 \\
\hline 2 & 0 & 0 & 1 & 2 & 6 & 5 \\
\hline 3 & 17 & 11 & 37 & 45 & 65 & 68 \\
\hline 4 & 61 & 53 & 109 & 104 & 103 & 101 \\
\hline 5 & 165 & 179 & 96 & 92 & 67 & 69 \\
\hline $\begin{array}{l}\text { Average } \\
\text { score }\end{array}$ & 4.6 & 4.7 & 4.2 & 4.2 & 3.9 & 4.0 \\
\hline
\end{tabular}

Table 7.21 Assessments by medical personnel in designated hospitals on prevention and control policies and plans for the phase with mild domestic cases $(n=189)$

\begin{tabular}{l|l|l|l|l|l|l}
\hline Score & Timeliness & Necessity & Rationality & Feasibility & Sustainability & Comprehensiveness \\
\hline 1 & 0 & 0 & 0 & 0 & 0 & 0 \\
\hline 2 & 0 & 0 & 0 & 1 & 1 & 1 \\
\hline 3 & 17 & 15 & 25 & 33 & 38 & 44 \\
\hline 4 & 52 & 49 & 89 & 84 & 88 & 77 \\
\hline 5 & 120 & 125 & 75 & 71 & 62 & 67 \\
\hline $\begin{array}{l}\text { Average } \\
\text { Score }\end{array}$ & 4.5 & 4.6 & 4.3 & 4.2 & 4.1 & 4.1 \\
\hline
\end{tabular}


Table 7.22 Assessments by medical personnel in designated hospitals on prevention and control policies and plans during peak periods of the epidemic with severe cases $(n=54)$

\begin{tabular}{l|l|l|l|l|l|l}
\hline Score & Timeliness & Necessity & Rationality & Feasibility & Sustainability & Comprehensiveness \\
\hline 1 & 0 & 0 & 0 & 0 & 0 & 0 \\
\hline 2 & 2 & 0 & 0 & 0 & 0 & 0 \\
\hline 3 & 6 & 4 & 5 & 8 & 8 & 9 \\
\hline 4 & 13 & 15 & 22 & 20 & 21 & 22 \\
\hline 5 & 33 & 35 & 27 & 26 & 25 & 23 \\
\hline $\begin{array}{l}\text { Average } \\
\text { Score }\end{array}$ & 4.4 & 4.6 & 4.4 & 4.3 & 4.3 & 4.3 \\
\hline
\end{tabular}

\subsubsection{Roughly Ninety Percent of Medical Personnel in Designated Hospitals Approved of the Timeliness of the Medical Treatment Measures}

The results of this study showed that $93 \%$ of the medical personnel polled felt that the medical treatment policies and measures during the imported case phase of the epidemic were timely or very timely, and no respondent felt that the measures were untimely or very untimely; $91 \%$ of the respondents felt that the measures were timely or very timely during the light domestic cases phase of the epidemic, again with no one finding them untimely or very untimely; and during the peak phase of the epidemic, $85 \%$ of those personnel felt that the measures were timely or very timely, with $4 \%$ feeling that the measures were untimely. There was a trend of declining approval of the timeliness of the measures shown in the responses.

\subsubsection{Over Ninety-Two Percent of Medical Personnel in Designated Hospitals Felt the Medical Treatment Measures Were Necessary}

The results of this study produced the following: $95 \%$ of medical personnel polled felt that the prevention and control along with medical treatment measures implemented during the imported case phase were necessary or very necessary, and no one felt them to be unnecessary; $92 \%$ of the respondents felt that the measures were necessary or very necessary during the light domestic case phase of the epidemic, again with no one feeling that they were unnecessary; and $93 \%$ felt the measures to be necessary or very necessary during the peak phase of the epidemic, with no one finding them unnecessary. The assessments regarding the necessity of these policies and measures remain relatively high. 


\subsubsection{Over Eighty-Four Percent of Medical Personnel in Designated Hospitals Approved of the Rationality of the Medical Treatment Measures}

The results of this study showed that $84 \%$ of medical personnel polled felt that the prevention and control as well as the medical treatment measures implemented during the imported case phase of the epidemic were either rational or very rational, with $0.4 \%$ who felt the measures were not rational; $87 \%$ of respondents felt that the measures implemented during the light domestic case phase were rational or very rational, with no one finding them to be not rational; and $91 \%$ of respondents felt the measures implemented during the peak phase of the epidemic to be rational or very rational, with no one finding them not rational. There was an upwards trend of more people believing in the rationality of the measures implemented.

\subsubsection{Over Eighty Percent of Medical Personnel in Designated Hospitals Approved of the Feasibility of the Medical Treatment Measures}

The results of this study showed that $80 \%$ of medical personnel polled felt that the prevention and control as well as the medical treatment measures implemented during the imported case phase of the epidemic were feasible or very feasible, with $0.8 \%$ finding the measures infeasible; $82 \%$ of the respondents felt the measures implemented during the light domestic case phase were feasible or very feasible, with a few individuals finding them infeasible; and $85 \%$ of the respondents felt the measures implemented during the peak phase of the epidemic were feasible or very feasible, with no one finding them infeasible. There was also an upwards trend in the perceived feasibility for these measures.

\subsubsection{Over Seventy Percent of Medical Personnel in Designated Hospitals Felt that the Medical Treatment Measures Were Sustainable}

The results of this study showed that $70 \%$ of the medical personnel polled felt that the prevention and control as well as the medical treatment measures implemented during the imported case phase of the epidemic were sustainable or very sustainable, with $3 \%$ finding the measures to be unsustainable; $79 \%$ of the respondents felt the measures implemented during the light domestic case phase were sustainable or very sustainable, with a few individuals finding the measures to be unsustainable; and $85 \%$ of respondents felt the measures implemented during the peak phases of the epidemic were sustainable or very sustainable, with no one finding them unsustainable. There was an upwards trend of perceived sustainability for these measures. 


\subsubsection{Over Seventy Percent of Medical Personnel in Designated Hospitals Felt that the Medical Treatment Measures Were Comprehensive}

The results of this study showed that $70 \%$ of medical personnel polled felt that the prevention and control as well as the medical treatment measures implemented during the imported case phase of the epidemic were comprehensive or very comprehensive, with $2 \%$ finding them uncomprehensive or very uncomprehensive; $76 \%$ of respondents felt the measures implemented during the light domestic case phase were comprehensive or very comprehensive, with only a few individuals finding them uncomprehensive; and $83 \%$ of respondents felt the measures implemented during the peak phase of the epidemic were comprehensive or very comprehensive, with no one finding them to be uncomprehensive. There was an upwards trend in the perceived comprehensiveness of these measures.

\subsubsection{A Comparison of Policy Assessments for Different Epidemic Phases}

Figure 7.20 outlines policy assessments for the first three phases of the epidemic, and from this comparison we can see that there is a downwards trend in perceived timeliness and necessity of the policies, and so the timing of policy adjustments may need further consideration. There is an upwards trend in believing in the rationality of the policies as well as their feasibility, sustainability and comprehensiveness. This shows that the entire process of Influenza A (H1N1) prevention and control was rational, and as we gained a deeper understanding of the virus and epidemic information, the medical policies gradually improved and became more sustainable.

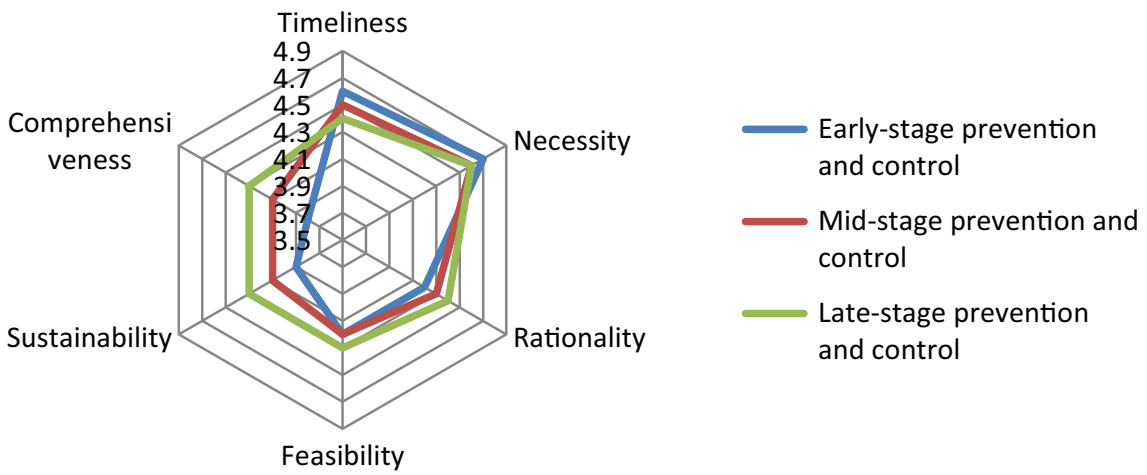

Fig. 7.20 Diagram of policy assessment for Influenza A (H1N1) prevention and control during the first three epidemic phases 


\subsubsection{Assessments from Personnel in the Disease Prevention and Control Agencies}

This study conducted surveys on 519 disease control personnel from Fujian, Guangdong, Sichuan, Henan, and Beijing to find out their understanding and assessment of prevention and control policies and measures. The results are as follows:

\subsubsection{Ninety-Five Percent of the Disease Control Personnel Felt that the Prevention and Control Efforts Against Influenza A (H1N1) Were Successful}

The results show that $95 \%$ of disease control personnel felt overall that the prevention and control of Influenza A (H1N1) was successful, and $67 \%$ felt that the overall input/output ratio for these efforts was proper. In comparison with the prevention and control of SARS, $75 \%$ felt the measures were timelier; $72 \%$ felt they were more open; $69 \%$ felt they were more transparent; $59 \%$ felt they were more rational; and $57 \%$ felt they were more effective (Table 7.23).

Among the disease control personnel, 95\% felt that the national strategies for the different phases were "fully consistent" or "mostly consistent" with the epidemic situation; 95\% felt that the strategies were consistent with objectives; 94\% felt that the measures were consistent with the strategies; and $90 \%$ felt that the measures were in line with the epidemic situation as seen in Table 7.24.

\subsubsection{Forty-Four Percent of Disease Control Personnel Felt It Was Necessary to Take Class a Infectious Diseases Management Measures}

Among the respondents, 90\% felt it was necessary to make Influenza A (H1N1) a statutory epidemic under the country's legislation. Among those, $70 \%$ thought Influenza A (H1N1) should be dealt with as a Class B infectious disease, and only $44 \%$ felt it was necessary to respond to it with Class A infectious disease management measures; $85 \%$ felt that the timing was appropriate in dropping it from Class A to Class B infectious disease and $83 \%$ felt that in the future it should be dropped from Class A to Class C (see Table 7.25). 


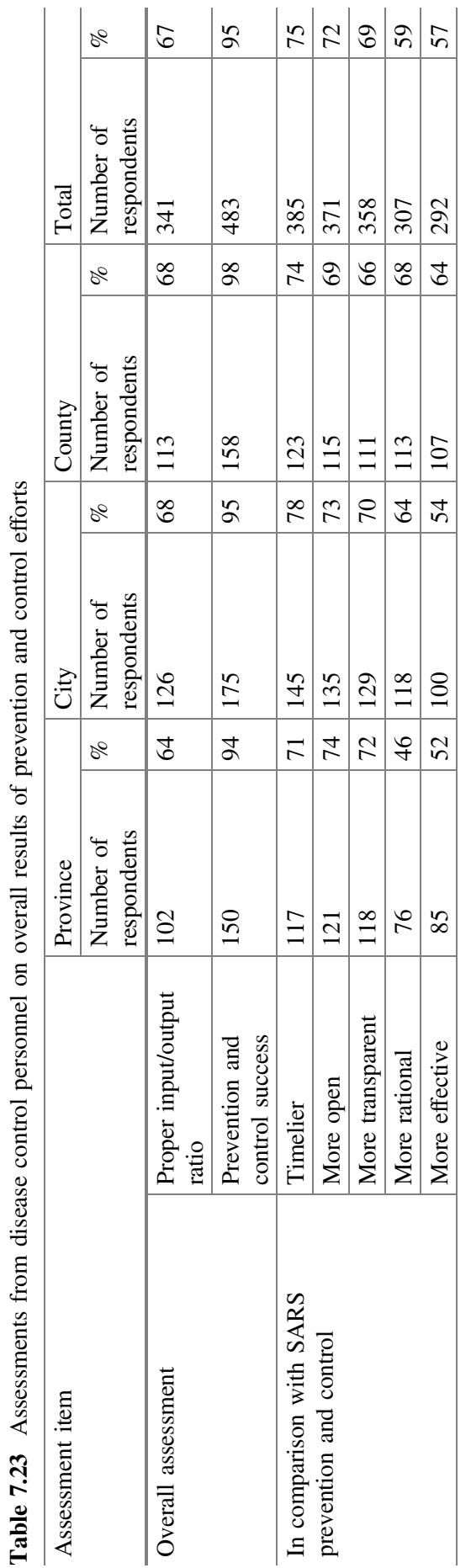




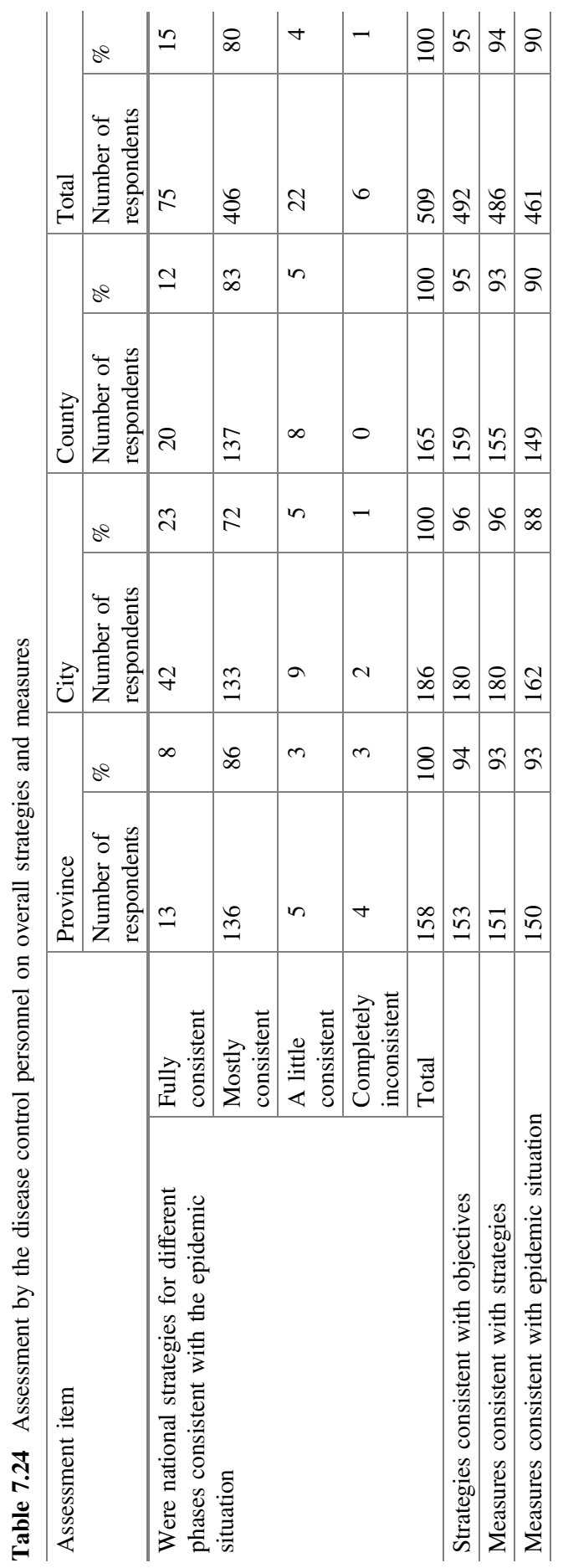


Table 7.25 Assessment by disease control personnel on incorporating legal management

\begin{tabular}{|c|c|c|c|c|c|c|c|c|}
\hline \multirow{2}{*}{$\begin{array}{l}\text { Assessment } \\
\text { item }\end{array}$} & \multicolumn{2}{|l|}{ Province } & \multicolumn{2}{|l|}{ City } & \multicolumn{2}{|l|}{ County } & \multicolumn{2}{|l|}{ Total } \\
\hline & $\begin{array}{l}\text { Number of } \\
\text { respondents }\end{array}$ & $\%$ & $\begin{array}{l}\text { Number of } \\
\text { respondents }\end{array}$ & $\%$ & $\begin{array}{l}\text { Number of } \\
\text { respondents }\end{array}$ & $\%$ & $\begin{array}{l}\text { Number of } \\
\text { respondents }\end{array}$ & $\%$ \\
\hline $\begin{array}{l}\text { Necessary to } \\
\text { make Influenza } \\
\text { A (H1N1) a } \\
\text { statutory } \\
\text { epidemic under } \\
\text { the country's } \\
\text { legislation }\end{array}$ & 142 & 89 & 170 & 94 & 143 & 87 & 455 & 90 \\
\hline $\begin{array}{l}\text { Necessary to } \\
\text { incorporate it } \\
\text { into class B } \\
\text { infectious } \\
\text { diseases }\end{array}$ & 111 & 77 & 138 & 82 & 88 & 62 & 337 & 74 \\
\hline $\begin{array}{l}\text { Necessary to } \\
\text { manage it as a } \\
\text { class A } \\
\text { infectious } \\
\text { disease }\end{array}$ & 67 & 49 & 87 & 54 & 34 & 26 & 188 & 44 \\
\hline $\begin{array}{l}\text { It's time to } \\
\text { reclassify it to } \\
\text { class B }\end{array}$ & 106 & 87 & 131 & 91 & 86 & 76 & 323 & 85 \\
\hline $\begin{array}{l}\text { Necessary to } \\
\text { incorporate it } \\
\text { into class } \mathrm{C} \text { in } \\
\text { future }\end{array}$ & 131 & 82 & 144 & 81 & 139 & 87 & 414 & 83 \\
\hline $\begin{array}{l}\text { Necessary to list } \\
\text { it into entry/exit } \\
\text { quarantined } \\
\text { diseases }\end{array}$ & 35 & 22 & 75 & 41 & 53 & 33 & 163 & 32 \\
\hline $\begin{array}{l}\text { Necessary to list } \\
\text { it into entry/exit } \\
\text { monitored } \\
\text { diseases }\end{array}$ & 64 & 41 & 100 & 56 & 100 & 61 & 264 & 53 \\
\hline $\begin{array}{l}\text { It's time to } \\
\text { reclassify it } \\
\text { from } \\
\text { quarantined } \\
\text { diseases to } \\
\text { monitored } \\
\text { diseases }\end{array}$ & 99 & 80 & 119 & 88 & 104 & 78 & 322 & 82 \\
\hline
\end{tabular}




\subsubsection{Ninety-One Percent of Disease Control Personnel Felt Adjustments in Close Contact Policies Suited the Epidemic Situation}

Table 7.26 shows that $81 \%$ of respondents thought that the management of close contacts was only necessary in the early days of the epidemic; $91 \%$ felt that adjustments in close contact measures suited the epidemic situation at that time; $84 \%$ felt the adjustment suited local conditions; and $85 \%$ felt that the timing was appropriate in adjusting close contact policies during the different epidemic phases.

\subsubsection{Eighty-Four Percent of the Disease Control Personnel Felt It Was Necessary to Expand the Epidemic Monitoring Network}

As show in Table $7.27,84 \%$ of respondents felt that the epidemic monitoring network needed to be expanded; $76 \%$ felt that the proper amount of expansion was conducted; and $78 \%$ felt that the expansion was realistic. What cannot be ignored is that $20 \%$ of respondents did not approve of this expansion, stating in the interviews that a large-scale expansion simply wasn't necessary and that choosing a few representative areas would suffice. These respondents felt that it was a waste of resources and that it would be unsustainable after the epidemic. In regards to the number of sentinel hospitals and laboratories along with the coverage of the monitoring network, how to distribute resources to properly meet the demands of prevention and control, and at the same time reduce inputs to ensure sustainability is an issue that requires further study.

\subsubsection{Comparison of Assessment on Several Major Prevention and Control Measures}

As Fig. 7.21 shows, concrete measures received fairly high approval rates of four and above. Building on this, in comparison we see that close contact management measures and adjustments received the lowest ratings, followed by case diagnostic processing and expansion measures for the epidemic monitoring network. Law-based management scored the highest among the assessments. Necessity and importance of these measures also received high ratings, however sustainability, comprehensiveness, and fairness scored relatively low which need to be strengthened in future policy formulation.

\subsubsection{Comparison of Assessment on Prevention and Control in Different Epidemic Phases}

In scoring the different epidemic phases, necessity, importance, and timeliness all received high ratings, but the rationality, feasibility, sustainability, 


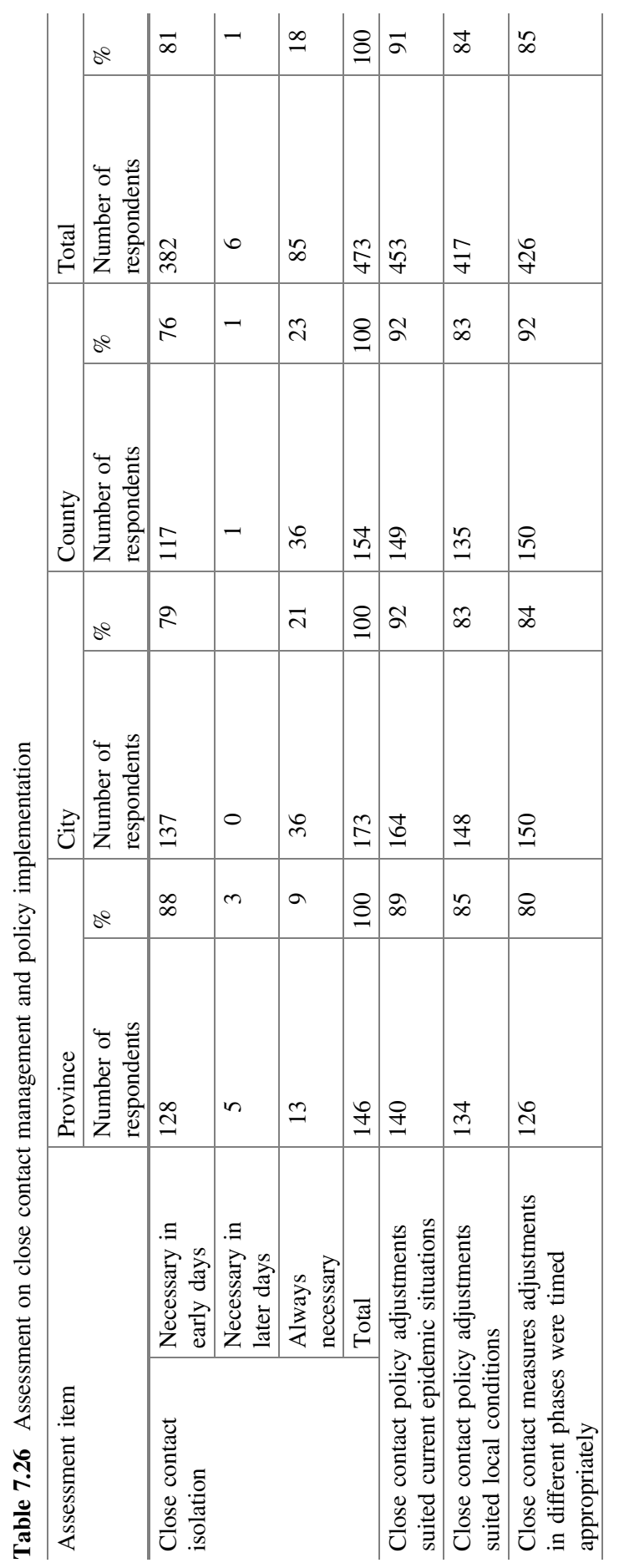


Table 7.27 Assessment on the expansion of the epidemic monitoring network

\begin{tabular}{l|l|l|l|l|l|l|l|l}
\hline Assessment & \multicolumn{2}{|l|}{ Province } & \multicolumn{2}{l|}{ City } & \multicolumn{2}{l|}{ County } & \multicolumn{2}{l|}{ Total } \\
\cline { 2 - 8 } item & $\begin{array}{l}\text { Number of } \\
\text { respondents }\end{array}$ & $\%$ & $\begin{array}{l}\text { Number of } \\
\text { respondents }\end{array}$ & $\%$ & $\begin{array}{l}\text { Number of } \\
\text { respondents }\end{array}$ & $\%$ & $\begin{array}{l}\text { Number of } \\
\text { respondents }\end{array}$ & $\%$ \\
\hline $\begin{array}{l}\text { Necessary to } \\
\text { expand } \\
\text { epidemic } \\
\text { monitoring } \\
\text { network }\end{array}$ & 134 & 85 & 159 & 87 & 128 & 78 & 421 & 84 \\
\hline $\begin{array}{l}\text { Scale of } \\
\text { expansion was } \\
\text { appropriate }\end{array}$ & 105 & 67 & 151 & 83 & 126 & 77 & 382 & 76 \\
\hline $\begin{array}{l}\text { Expansion } \\
\text { policies were } \\
\text { realistic }\end{array}$ & 111 & 71 & 154 & 85 & 127 & 77 & 392 & 78 \\
\hline
\end{tabular}
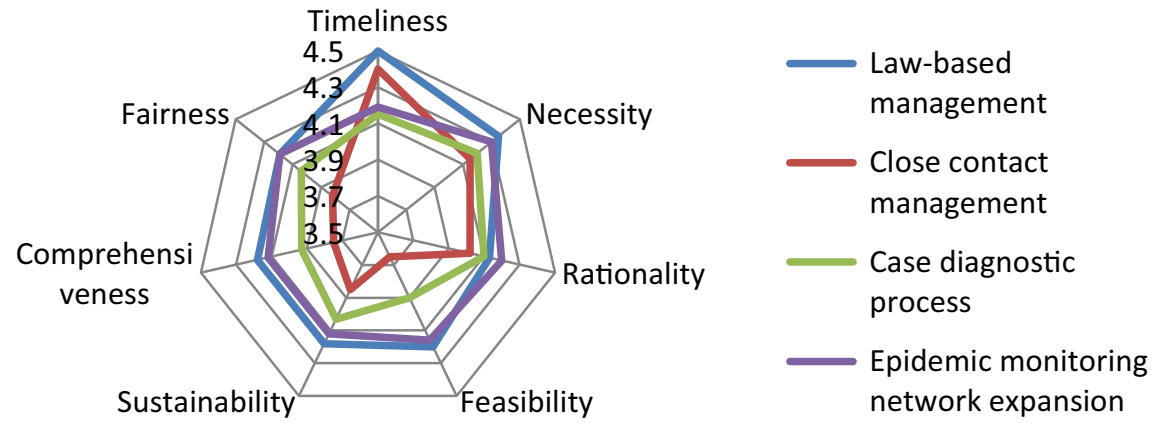

Fig. 7.21 Comparison diagram of Influenza A (H1N1) prevention and control policies

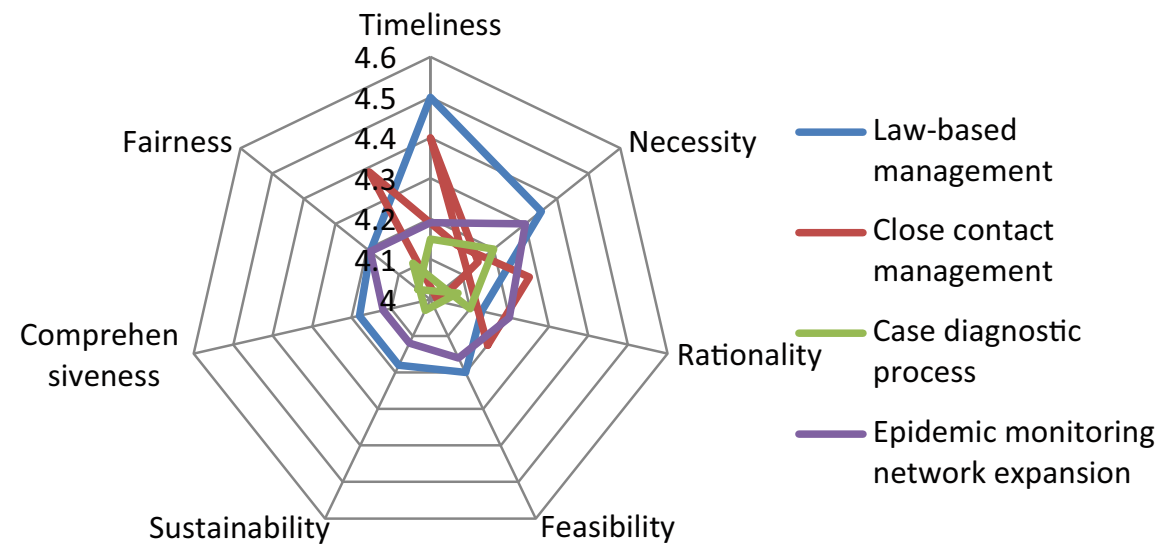

Fig. 7.22 Comparison diagram of assessment on prevention and control polices in the different epidemic phases 
comprehensiveness, and fairness of the policies and measures scored relatively low. Among those, besides the high score of "timeliness" in the imported case phase, all other items scored relatively low in this phase (as seen in Fig. 7.22).

\subsection{Assessments from the International Community}

One key characteristic of the prevention and control efforts against the Influenza A (H1N1) pandemic was widespread and strategic international cooperation. Understanding international assessments on the national prevention and control efforts will provide us with a more comprehensive and objective view into our own successes and setbacks. Therefore, we conducted in depth interviews with WHO officials stationed in Beijing and we conducted a literature review on the international media surrounding the pandemic.

\subsubsection{WHO's Assessment on Our National Influenza A (H1N1) Prevention and Control Efforts}

\subsubsection{China's Overall Prevention and Control Strategies Were Consistent with Their Domestic Realities}

Looking at the overall picture of their prevention and control strategies, from the very beginning China adopted a containment strategy and also adopted other control measures like close contact isolation, and held these measures in place over a long period of time. The transition to the mitigation phase did take a little longer than in other countries as this decision took into consideration China's domestic realities. China's medical treatment capabilities are weaker than developed countries like the U.S., and thus the country needs to strengthen its first line of defense. However, this type of containment strategy expends a large amount of resources and manpower, and as soon as the epidemic spreads, containment is no longer efficient. In regards to vaccinations, China was the first developing country to successfully research and implement inoculations. The WHO offered guidance to many countries as well as information to help with decision-making, and China's prevention and control measures in many areas were quite stringent.

\subsubsection{China's Influenza A (H1N1) Monitoring Capabilities Garnered Worldwide Recognition}

In comparison with other developing countries, China possesses strong monitoring capabilities. China's disease surveillance is part of the WHO system, and both the 
WHO and the China CDC have enjoyed a long period of close collaboration. Both kept close contact through phone conferences during this pandemic. The collaboration between the China $\mathrm{CDC}$ and the WHO is already in its second Five-Year Plan (2005-2010); the WHO helped China build their disease monitoring system, including the construction of monitoring sites in 23 provinces and sites in some cities. In November 2010, Chinese National Influenza Center (CNIC) of National Institute for Viral Disease Control and Prevention under the Chinese Center for Disease Control and Prevention, through the WHO Evaluation, became the fifth WHO Collaborating Centre for Reference and Research on Influenza and also the first developing country to enter the "core circle" for the international disease monitoring network. Because of this, China's disease monitoring capabilities have garnered worldwide recognition.

\subsubsection{It Would Be Difficult to Respond to a Severe Epidemic with China's Current Medical Treatment Capabilities}

During the Influenza A (H1N1) epidemic, China's medical treatment capabilities did improve on a national scale; however, overall, the requirements for these capabilities were relatively low since this epidemic was mild with few severe cases. If a severe epidemic did occur, there would be risks with China's current treatment capabilities. Additionally, in comparison with other countries, China has a smaller stockpile of the drug Tamiflu.

\subsubsection{There Was Significant Progress in the Chinese Government's Risk Communication Capabilities}

Each country has its own contextual history, and for China, there has been a significant improvement in its crisis communication capacity since the SARS outbreak. At the very start of the Influenza A (H1N1) epidemic, the Ministry of Health and the China CDC were in close communication with the WHO, as China and the WHO had already begun risk communication collaboration as outlined in the Five-Year Plan. Risk communication must start at the beginning of an outbreak, and public understanding of decision-making is only achieved on the basis of strong communication with the public. The U.S., which was still able to provide leadership and guidance for the public and medical agencies at the onset of the epidemic even though there were still many uncertainties as to the nature and danger of the virus. China's government, on the other hand, did not effectively assume this role at the beginning of the epidemic. 


\subsubsection{The International Media's Assessment on China's Influenza A (H1N1) Prevention and Control}

Generally speaking, mainstream media worldwide and some experts evaluated China's Influenza A (H1N1) prevention and control positively, but they have expressed reservations about the effects of the measures.

\subsubsection{Mainstream Media "Mostly Positive"}

The mainstream media did not provide a lot of judgments on the actions of the Chinese government for this epidemic, nor were there any clear criticisms. The majority of news reports were objective and rational, and simply covered the facts; there were few that provided any evaluations. In other words, most of the reports focused on a few key countries, including China, and provided introductions to the outbreaks, developments, and prevention and control efforts; there were very few that provided any assessments of these developments. In a sense, this phenomenon could mean that China's emergency management was suited to the task this time around which left little for the media to criticize. Taking into account mainstream media leans more towards "criticism and not praise" and the influx of criticism from foreign media for the SARS outbreak, we could interpret this phenomenon as a more positive international response to China's Influenza A $(\mathrm{H} 1 \mathrm{~N} 1)$ prevention and control efforts.

\subsubsection{Most Expressed Understanding and Approval of the Prevention and Control Measures}

Both public and expert opinion overall showed that, although there were criticisms, most understood and approved of the strict prevention and control measures China adopted in response to the Influenza A (H1N1) epidemic.

During the onset of the outbreak, the Chinese government's decision to segregate and isolate all of the passengers on the plane was criticized. Of course, the most intense criticism came from the Mexican government, especially the Minister of Foreign Affairs, Patricia Espinosa. She stated that the treatment of Mexican citizens in China was "discriminatory" and that some of the quarantined people were in "unacceptable conditions." "U.S. Congress also criticized the isolation procedures by issuing tactful travel warnings. The isolation and medical detention adopted by China was called an "offensive" prevention and control measure in The New York Times, and China was also criticized for being inflexible, as the author

\footnotetext{
${ }^{1}$ Austin Ramzy, China and Swine Flu: Are Mexicans Being Singled Out? http://www.time.com/ time/world/article/0,8599,1895659,00.html\#ixzz13bdWvTmF, May 4, 2009.
} 
felt these type of measures "are easy to implement in authoritarian countries."2 Other foreign professionals who experienced isolation measures also expressed their dissatisfaction. Psychiatry professor Jonathan M. Metzl from the University of Michigan felt that the isolation he experienced was "against public health regulations and xenophobic in nature;" he also felt that the isolation measures adopted were "completely inappropriate." 3 Other public opinions felt that the measures were "redundant." The Wall Street Journal also had criticisms on the state's actions: "The government's attempts to quarantine all arriving passengers suspected of carrying $\mathrm{H} 1 \mathrm{~N} 1$ - and those seated around them on aircraft-has been overzealous." " On the other hand, CNN stated in a report on September 16th that "China has had perhaps the most extreme and active response to the virus than any other country in the world." 5

However, a considerable amount of public opinion also reflected an understanding of these measures. On November 11th, 2009, The New York Times quoted a U.S. school teacher who had been isolated in this passage: "At the time, it seemed extreme, and it seemed restrictive, because I had never experienced an infectious disease outbreak. Now, looking back and seeing some of the measures that are being taken now in the U.S., the Chinese measures don't seem so extreme."6 MSNBC also pointed out that, "China was hit hard before by SARS, it's understandable as to why they are so worried about another outbreak of an infectious disease." BBC News also stated that "This time the government has acted quickly and decisively." 7

In November 2009, the head of the WHO Office in Beijing officially approved of China's response measures to Influenza A (H1N1) stating, "I think there were a variety of measures put in place by different countries, and it's difficult to say what worked best and what didn't, but China's has worked very well.",

\footnotetext{
${ }^{2}$ Edward Wong, China's Tough Flu Measures Appear to Be Effective, http://www.time.com/time/ world/article/0,8599,1895659,00.html, November 11, 2009.

${ }^{3}$ Jonathan M. Metzl, China's Ill-Considered Response to the H1N1 Virus, http://articles.latimes. com/2009/jul/12/opinion/oe-metzl12, July 12, 2009.

${ }^{4}$ Jeremy Chan, China Tries to Head Off Rural Flu Outbreak, http://online.wsj.com/article/ SB124656091632187681.html?KEYWORDS=China+H1N1, July 2009.

${ }^{5}$ Emily Chang, Inside China's H1N1 Vaccine Laboratories, http://articles.cnn.com/2009-09-16/ world/china.swine.flu.vaccine_1_sars-vaccine-sinovac-biotech-h1n1?_s=PM:WORLD,September 16th, 2009.

${ }^{6}$ Edward Wong, China's Tough Flu Measures Appear to Be Effective, http://www.time.com/time/ world/article/0,8599,1895659,00.html, November 11, 2009.

${ }^{7}$ Swine flu found on China mainland, http://news.bbc.co.uk/2/hi/asia-pacific/8043189.stm.

${ }^{8}$ Edward Wong, China's Tough Flu Measures Appear to Be Effective, http://www.time.com/time/ world/article/0,8599,1895659,00.html, November 11, 2009.
} 
Some media reported on foreign visitors who received top notch treatment from the Chinese government during isolation. On May 28th, 2009, The New York Times quoted a tourist who explained that the Chinese officials worked very hard to make the isolated tourists feel at home, that the Minister of Culture actually sent fruit and flowers and a band to play for the foreign students during isolation. Although the students naturally were bored and frustrated, they still felt that "the Chinese were very friendly." The Washington Post also cited a tourist who stated, "I was definitely happy I was treated nicely." 10

What received the most approval was the "unusual openness" of China's information disclosure both to the public and other countries. According to The New York Times, some researchers felt that the biggest difference between the SARS outbreak and the Influenza A (H1N1) pandemic was the amount of information disclosed by the government.

"Aggressive," "strict," "tough," and "all-court press" were the adjectives used by the international media to describe the actions by the Chinese government. The U. K.'s The Times described China's Influenza A (H1N1) prevention and control methods as "the world's most stringent."

\subsubsection{There Was Significant Progress in Prevention and Control Since SARS}

All the praise garnered for China's Influenza A (H1N1) prevention and control efforts to a certain extent came from the comparison of their efforts in 2003 against SARS. When the international media assesses the Influenza A (H1N1) response, they always cite the measures adopted during SARS. A large portion of reports that talk about China's Influenza A (H1N1) epidemic draw comparisons to the 2003 SARS outbreak. One representative piece from the Wall Street Journal (July 2009) cited, "With fresh memories of its failed coverup of the SARS outbreak in 2002, China this time has been notably more open and aggressive in its response to H1N1." 12

\footnotetext{
${ }^{9}$ Doug Donovan, Worried About Flu, China Confines U.S. Students, May 28, 2009.

${ }^{10}$ Ariana Eunjung Cha, Caught in China's Aggressive Swine Flu Net, The Washington Post, May 29, 2009.

${ }^{11}$ Jane Macartney, China Adopts Stringent Measures to Contain Spread of Swine Flu, http://www. timesonline.co.uk/tol/news/uk/health/article6719469.ece, July 20, 2009.

${ }^{12}$ Jeremy Chan, China Tries to Head Off Rural Flu Outbreak, http://online.wsj.com/article/ SB124656091632187681.html?KEYWORDS=China+H1N1, July 2009.
} 


\subsubsection{Questions Arose Around the Isolation Measures and Vaccination Effectiveness}

The international opinion around China's isolation measures were doubtful of its effectiveness and high cost. For example, the Los Angeles Times made their opinion clear: "So is China's aggressive approach, which has quarantined thousands of Americans and others, the proper way to protect its population from the new flu? No."13 There was positive feedback regarding China's Influenza A (H1N1) vaccination, but there were also suspicions regarding its effectiveness. For example, Australia's The Age expressed the concern that although the vaccination is at the international forefront of development, it still poses a safety issue. ${ }^{14}$

\subsubsection{Recommendations from International Public Opinion}

The CSIS Commission on Smart Global Health Policy stated that when responding to an infectious disease outbreak, the public's trust in their government comes from "having no secrets." In view of the fact that the lack of trust in the government during the SARS period led to the rapid spread of the disease, this time around the Chinese government and media must learn from the past and promote public cooperation and trust through whatever effective measures are available. ${ }^{15}$

The Los Angeles Times also purported that, "Many countries-the U.S. included - have tended to see viral illness as coming from 'outside,' only to learn that pandemics show little respect for national borders in a globalized world. Chinese health authorities need to wake up to this lesson and develop China's ongoing H1N1 response in concert with, rather than in rejection of, international norms." 16

\subsection{Overall Evaluations from Different Parties}

In combination with the survey results of satisfaction with state prevention and control efforts from patients, close contacts, and medical institutions, along with the survey findings on the impact of Influenza A (H1N1) on the credibility of the government and international assessments, the following conclusions can be made.

\footnotetext{
${ }^{13}$ Jonathan M. Metzl, China's Ill — Considered Response to the H1N1 Virus, http://articles.latimes. com/2009/jul/12/opinion/oe-metzl12, July 12, 2009.

${ }^{14}$ China Approves One — dose Homegrown Swine Flu Vaccine, http://news.theage.com.au/breakingnews-world/china-approves-onedose-homegrown-swine-flu-vaccine-20090903-f9qj.html.

${ }^{15}$ China's H1N1 Response and Public Opinion: Promise and Potential Challenges, http://www. smartglobalhealth.org/blog/entry/china.

${ }^{16}$ Jonathan M. Metzl, China's Ill — Considered Response to the H1N1 Virus, http://articles.latimes. com/2009/jul/12/opinion/oe-metzl12, July 12, 2009.
} 


\subsubsection{There Was High Praise for the State's Influenza A (H1N1) Response Measures}

The results from this study showed that almost $92 \%$ of the public polled were satisfied with the central government's prevention and control efforts, among which $44.9 \%$ were very satisfied and only $0.25 \%$ expressed clear dissatisfaction; $85 \%$ of respondents also were satisfied with their local governments. Additionally, $95 \%$ of disease control professionals felt that the measures were an overall success, and $84 \%$ of close contacts along with $65 \%$ of patients expressed satisfaction towards the treatment they were given (The overall satisfaction of patients and close contacts was lower than the public's, which is understandable as they were the targets of these measures. They were constrained in the isolation and treatment process, their level of satisfaction naturally decreased).

\subsubsection{There Was a General Consensus that There Was Significant Improvement in the State's Health Emergency Management Capabilities}

The Chinese government's work in information disclosure and openness during the prevention and control of Influenza A (H1N1) garnered widespread approval as the information supplied by the government became the public's most trusted news source. The public also approved of the government's emergency response capabilities, especially in regards to their local governments, as there was a clear improvement in capabilities since SARS. After they experienced Influenza A (H1N1), 96.1\% of the public polled expressed trust in the central government's emergency response capabilities, and $94 \%$ of the public expressed trust in their local governments' emergency response capabilities. Compared with the time of SARS, $63.8 \%$ of the public trusted the central government's emergency response capabilities more and $58.1 \%$ expressed more trust in their local governments' emergency response capabilities, which shows significant improvement. In addition, $95 \%$ of close contacts and $82 \%$ of patients felt that the government made improvements in their public health emergency management. The distinct transition of $30.7 \%$ of the respondents from distrust to trust of the local government's capabilities is a clear indication of the significant progress the state has made in emergency management and public communication. 


\subsubsection{There Was an Overall Recognition of the Necessity of the State's Prevention and Control Measures}

Out of the population that was directly affected by the prevention and control measures, $93 \%$ of patients, $93 \%$ of close contacts, and $92 \%$ of medical personnel in designated hospitals all agreed to the necessity of these measures. Over $90 \%$ of the general public polled also saw the necessity of certain prevention and control measures. Over $84 \%$ of the medical personnel in designated hospitals approved of the rationality of the treatment measures adopted, and $91 \%$ of disease control personnel felt that the close contact measures adopted were consistent with the current epidemic situation. The WHO also felt that the overall strategy matched China's epidemic realities, and the disease monitoring system garnered worldwide recognition for its success.

\subsubsection{Generally Speaking All Parties Approved of the Timeliness and Appropriateness of the Prevention and Control Measures, but Some Controversy Still Exists}

Roughly $90 \%$ of medical personnel in designated hospitals felt that the prevention and control strategies and measures were adjusted in a timely manner; however, this proportion was lower in the general public, with only $70 \%$ feeling that the adjustments were timely. The WHO office in Beijing felt that the transition from "containment" to "mitigation" was a little slower than other countries, and that the cost for containment was rather high.

In regards to the measures adopted, only $50 \%$ of the public felt them to be appropriate, with roughly $20 \%$ stating the measures were relatively strict. Additionally, $17 \%$ of patients and $11 \%$ of close contacts felt that the measures adopted at the onset of the epidemic were relatively strict. Some industries and professionals felt the measures to be excessive, and the level of satisfaction was relatively low. For example, the overall satisfaction expressed from military members in regards to prevention and control efforts by the central and local government was relatively low. There was higher proportion of neutrality or dissatisfaction among people working in the hotel and restaurant sectors as well as education sector in regards to the central and local governments efforts against Influenza A (H1N1). This could be because the measures adopted placed more pressure on the military and education sectors, and also had a negative impact on the hotel/restaurant businesses.

Roughly $30 \%$ of the public polled felt that the government invested a lot into its prevention and control efforts. However, the proportion of patients and close contacts that felt the investment by the government was worth it is relatively higher 
than that of the public, with $84 \%$ of patients and $82 \%$ of close contacts seeing the worth of state investment. It's clear from these numbers that state investment in the prevention and control efforts was widely approved of and supported by the affected population.

\subsubsection{There Were Some Differences in Assessments Regarding Other Specific Prevention and Control Measures}

Taking management of Class A infectious diseases as an example, less than half of the disease control personnel felt that Influenza A (H1N1) needed to be classified for Class A management, most just felt that in the future this virus should be downgraded to a Class $\mathrm{C}$ infectious disease. At the same time, there were similar issues in diagnosis procedures. Almost $40 \%$ of respondents felt it was not necessary to ask the higher authorities to confirm the diagnosis; most respondents in fact felt this procedure wasted a large amount of manpower and resources, and that it was completely unnecessary. Thus, the formulation of certain prevention and control measures will need improving in the future. 